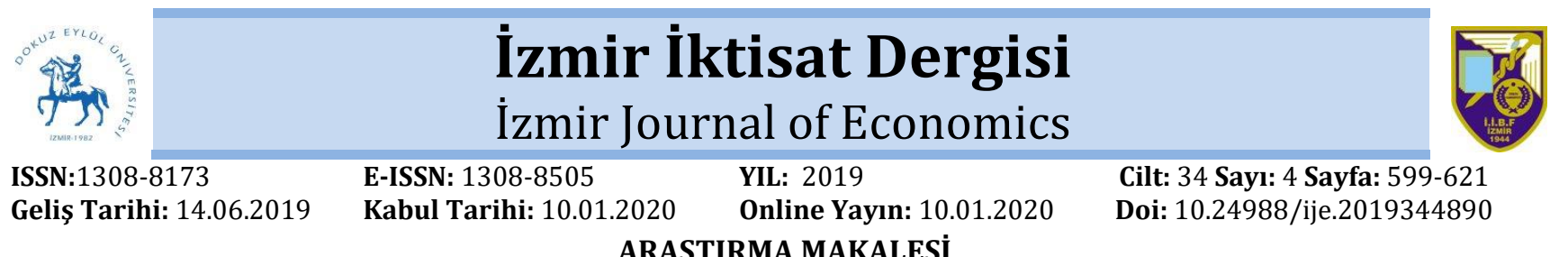

ARAŞTIRMA MAKALESI

\title{
İnsan Haklarına Duyarlı Bütçeleme Analizi: Türkiye Örneği ${ }^{1}$ \\ Gonca GÜNGÖR GÖKSU 2 \\ Özet
}

Insan haklarına duyarlı bütçeleme dezavantajlı grupların durumlarının iyileștirilmesi için önem verilen sosyal bütçeleme uygulamalarından birisidir. Bu bütçeleme yaklaşımı bir bütçe tekniğinden ziyade, bireysel ve toplumsal ihtiyaçların en hızlı ve en etkili bir şekilde karşılanması için devlet bütçelerinin nasıl hazırlanması konusunda yol gösteren bir uygulamadır. Bu çalışmada Türkiye'de merkezi yönetim bütçesi kapsamında insan hakları ile ilişkili bütçe kalemleri belirlenmiștir. İnsan hakları ile ilișkili bütçe kalemleri belirlenirken kamu hizmetleri, fonksiyonel sınıflandırmaya göre gruplandırılmıștır. Çalışmanın son bölümünde insan hakları ile ilişkili bütçe tahsislerinin ve kamu harcamalarının, Birleşmiş Milletler tarafından belirlenen ve tüm üye ülkelerin uymak zorunda olduğu yükümlülükleri karşılayıp karşılamadığı araștırılmıştır. Çalışmanın zaman kısıdı 2006 -2018 yılları arasıdır. 2006-2017 yıllarına ait veriler Bütçe ve Mali Kontrol Genel Müdürlüğünün resmi internet sitesinden, 2018 yılına ait veriler ise Muhasebat Genel Müdürlüğünün resmi internet sitesinden derlenmiştir. Çalışmanın amacı; insan hakları ile devlet bütçesi arasındaki ilişkiyi vurgulamak ve Türkiye'de insan haklarına duyarlı bir bütçeleme analizi yapmaktır.

Anahtar kelimeler: İnsan Hakları, İnsan Haklarına Duyarlı Bütçeleme Analizi, Türkiye Jel Kodu: H61, H72, K38

\section{Human Rights Budgeting Analysis: The Sample of Turkey Abstract}

Human rights budgeting is an application of social budgeting that places importance on improving the situations of disadvantaged citizens. Rather than a budget technique, this budgeting approach is an application that guides how state budgets should be designed to be provided the needs of individuals and society fastest and most effective. In this study, the budget items which are related to human rights are determined in the context of the central government budget in Turkey. While determining the relationship between human rights and budget items, public services have been grouped according to functional classification. In the last part of the study, it has been researched that whether the budget appropriations and expenditures related to human rights meet the obligations set by the United Nations, and which all member states must comply with. The time limit of the study is between 2006-2018 years. The data belonged to 2006-2017 years have been collected from the official websites of the General Directorate of Budget and Financial Planning (BUMKO), and the data belonged to the 2018 year have been collected from the official website of the General Directorate of Public Accounts. The study's aim is to highlight the relationship between human rights and state budget and to perform a human right budgeting analyze in Turkey.

Keywords: Human Rights, Human Rights Budgeting Analysis, Turkey Jel Codes: H61, H72, K38

\section{GíRiş}

İnsan hakları, ırk, dil, din ayrımı olmaksızın tüm insanların yararlanacağı haklar (Gözler, 2017:60) olup, onurlu bir yaşam ile yakından ilişkilidir. Bireylerin onurlu bir yașam sürdürebilmeleri için gerekli olan temel hak ve özgürlüklerden yoksun olması ise bireyleri dezavantajlı konuma getiren ve arzu edilmeyen sonuçlar doğurmaktadır. Bu sebeple devlet yöneticilerine temel hak ve özgürlüklerin sağlanması noktasında pek çok görev düşmektedir ${ }^{4}$. Çünkü vatandaşlar, devlet yöneticilerinden temel ihtiyaçlarını sağlamalarını, özellikle acil sağlık, temel eğitim,

\footnotetext{
${ }^{1}$ Bu çalışma 12-14 Eylül 2018 tarihlerinde Safranbolu'da düzenlenen Business \& Organization Research Conference kapsamında özet olarak sunulmus bildirinin gözden geçirilmiş ve genişletilmiş tam metnidir.

${ }^{2}$ Araș. Gör. Dr., Sakarya Üniversitesi, Siyasal Bilgiler Fakültesi, Maliye Bölümü, SAKARYA

EMAIL: ggungor@sakarya.edu.tr ORCID: 0000-0003-0230-7391

3 "Kamu malî yönetim sistemimizi uluslararası standartlara uygun bir șekilde yapılandıran 5018 sayılı Kamu Mali Yönetimi ve Kontrol Kanunu (KMYKK) 2006 yılından itibaren bütün maddeleriyle birlikte yürürlüğe girmiştir.”(TBMM, 2006). Bu sebeple 2006 yılı analizin başlangıç yılı olarak seçilmiştir.

4 Örneğin; 1982 Anayasasının 5. maddesine göre devletin temel amaç ve görevleri şöyle tanımlanmıștır: "Türk Milletinin bağımsızlığını ve bütünlüğünü, ülkenin bölünmezliğini, Cumhuriyeti ve demokrasiyi korumak, kişilerin ve toplumun refah, huzur ve mutluluğunu sağlamak; kişinin temel hak ve hürriyetlerini, sosyal hukuk devleti ve adalet ilkeleriyle bağdaşmayacak surette sınırlayan siyasal, ekonomik ve sosyal engelleri kaldırmaya, insanın maddî ve manevî varlığının gelişmesi için gerekli şartları hazırlamaya çalışmaktır."
} 
barınma, korunma, gıda vb. alanlarda halkı desteklemelerini beklemektedirler.

Birleşmiş Milletler tarafından 1976 yılından itibaren uygulanan Ekonomik, Sosyal ve Kültürel Uluslararası Sözleşmesi gereği, devletlerin uyması gereken bir takım yasal yükümlülükler belirlenmiştir. Bahsi geçen yükümlülükler arasında insan haklarına ayrılan kaynakların mümkün olduğunca en üst düzeyde kullanılması, sunulan hizmetlerde sürekli bir iyileştirme yapılması, mevcut durumunun ilerleyen dönemlerde kötüleşmesine izin verilmemesi ve asgari düzeyde de olsa temel hakların tüm vatandaşlara yönelik sağlanması yer almaktadır. $\mathrm{Bu}$ doğrultuda insan haklarına duyarlı bütçeleme olarak adlandırılan bir uygulama geliştirilmiştir.

Başlangıçta bir bütçe tekniği gibi algılansa da aslında bu yaklaşım sosyal bütçe uygulamalarından sadece birisidir. Sosyal bütçeleme uygulamaları; cinsiyete duyarlı bütçeleme, katılımcı bütçeleme, vatandaş odaklı bütçeleme, insan haklarına duyarlı bütçeleme ve çocuklara duyarlı bütçeleme olarak beş temel gruba ayrılmaktadır (Çiçek ve Dikmen, 2016: 137). Sosyal bütçe uygulamalarının ortak amacı ise bireylerin ihtiyaçlarını karşılamak ve toplumsal eşitliği sağlamaktır. Uygulamaların özünde evrensellik ${ }^{5}$, eşitlik, șeffaflık, hesap verebilirlik ve katılımcılık olmak üzere beș ana insan hakları ilkesine dayanmaktadır. Günümüzde de giderek önemi artan bu uygulama ile devlet bütçeleri hazırlanırken toplumsal refahı arttırmak için ne gibi önlemlerin alınması gerektiğine vurgu yapılmaktadır.

Çalışmada insan haklarına duyarlı bütçelemenin tamamlayıcı olan insan haklarına duyarlı bütçeleme analizi konusu incelenmiş ve Türkiye özelinde bir değerlendirme yapılmıştır. Çalışma kapsamında öncelikle teorik çerçeve açıklanmıştır. Çalışmanın ilerleyen kısımlarında ise insan hakları ile ilişkili merkezi yönetim bütçe ödeneklerinin ve harcamalarının analizi yapılmıştır. Çalışmada bütçe ödenek tahsisi analiz yöntemi ile bütçe harcamaları analiz yöntemi tercih edilmiştir. $\mathrm{Bu}$ sebeple öncelikle gerçekleșen bütçe harcamalarının bütçe ödeneklerini yüzde kaç düzeyinde karşıladığı araştırılmaktadır. Bir sonraki aşamada ise gerçekleșen harcamaların artış oranları incelenmektedir. Çalışmada veriler ulusal düzeyde bütçe analizi kapsamında kullanılmıştır. Zaman sınırlaması açısından değerlendirildiğinde, dinamik analiz yöntemi tercih edilmiştir. Bu doğrultuda 20062018 yılları arasındaki 13 yıllık süreci içeren veriler üzerinden bir analiz yapılmaktadır. Çalışma hazırlanırken insan hakları ile devlet bütçesi arasındaki ilişkinin vurgulanması ve Türkiye'de kamusal kaynakların kullanımında insan haklarına duyarlı bütçeleme analiz edilmesi amaçlanmıştır.

\section{INSAN HAKLARI KAVRAMI VE GELIŞSiMI}

İnsan hakları evrensel kabul gören temel bir değer olup, insana insan gibi muameleyi gerektirmektedir. İnsanlar arasında ayrım yapılmaksızın insan onuruyla bağdaşan şekilde davranmak ve bireylerin özgür ve eşit olduğu bilincinin tesis edilmesi insan hakları kavramının temelini oluşturmaktadır (Çoşkun, 2004:83). Örneğin; bazı ülkelerin teknolojik açıdan gelişmiş olması, onların diğer kültürlerden daha üstün olduğu anlamına gelmemektedir. Çünkü hiçbir kültür veya bölge diğer kültürlere veya bölgelere egemen değildir. İnsan hakları hareketi pozitif açıdan değerlendirildiğinde tüm kültürler eşittir (Mutua, 1995:657).

İnsan hakları, insan onuruyla ilişkilidir ve hakların kazanılmasında bu onurun tanınması ve saygı gösterilmesi gerekmektedir. İçinde bulunduğumuz dönemde devletler özgürce ve hiçbir zorlama olmaksızın, yeterli bir yaşam standardına, barınma imkânına, eğitim/sağlık hizmetlerinin sunulmasına, çocukların, 
kadınların ve azınlık kesiminin ekonomik, sosyal ve kültürel haklarının korunmasına yönelik bazı uluslararası yükümlülükler üstlenmiştir (FLAC, 2014:1). Çünkü insan hakları sadece şiddet biçimleriyle ilgili değildir (Wright, 2001:7). Haklar aynı zamanda geniş bir yelpazeye sahiptir. Bu yasal haklar, bazı ilkeler kapsamında yönlendirilmelidir: Haysiyet, (ii) Eşitlik, (iii) İnsan haklarının kullanılmasında ayrımcılık yapılmaması ve (iv) Bütçeleme sürecine dâhil edilmesi gereken siyasi tercihler ve yasal insan hakları yükümlülükleri konusunda toplum genelinde devam eden bir diyalogun sağlanmasıdır (FLAC, 2014:1).

İnsan hakları kavramı bilim insanları tarafından hukuki, felsefi, ahlaki ${ }^{6}$ vb. açılardan farklı şekillerde açıklanmaktadır. Örneğin; Kuçuradi (1996:49) insan haklarını "değerli bir varlık olan insan türünün sahip olduğu imkanları gerçekleştirilebilmek amacıyla ihtiyaç duyulan koşulları talep eden ilkeler" olarak tanımlamaktadır. O'na göre insanların sahip oldukları ek özellikler ya da imkanlar, insan onurunu ve insanın değerini belirlemektedir. Shue'ye (1996:30-37) göre ise insan hakları kısaca "varlığını sürdürme hakları" olarak ifade edilmektedir. Daha açık bir ifadeyle; asgari geçimini temin edemeyenlere yönelik su, yeterli gıda, giyecek, barınma, acil sağlık ve temel eğitim hizmetlerinin karşılanması zorunluluğu bulunmaktadır (Şahin Taşğın, 2017:203-204).

Uluslararası anlaşmalar ve diğer yasal belgeler tarafından tanımlanan insan hakları; medeni ve siyasi hakların yanı sıra ekonomik, sosyal ve kültürel haklardan oluşmaktadır. Bununla birlikte insan hakları işçi haklarını, yeterli bir yaşam standardına sahip olma hakkını, sosyal güvenlik hakkını ve yiyecek, barınma, giyim, eğitim ve sağlık haklarını içermektedir (Alston, 2004:32). Ayrıca haklar arasında hiyerarşi olmayıp, bir hakkın geliştirilmesi için diğer bir hak bastırılamaz (UNDP, 2015:8).
Levin tarafından hazırlanan ve Birleşmiş Milletler Eğitim, Bilim ve Kültür Örgütü (UNESCO) tarafından basılan "İnsan Hakları: Sorular \& Cevaplar" isimli çalışmaya göre insan hakları kavramının iki temel anlamı vardır. Birincisi, içsel ve devredilemez olan haklardır. Bunlar her insanın, insanlığından türetilen ahlaki haklardır ve her insanın onurunu sağlamayı amaçlamaktadır. İnsan haklarının ikinci anlamı ise hem ulusal hem de uluslararası toplumların yasa oluşturma süreçlerine göre belirlenen yasal haklardır. Bu hakların temeli yönetilenin rızasına dayanmaktadır (Levin, 1987:11). Gözler tarafından hazırlanan çalışmada ise literatürde yer alan insan hakları kavramları aşağıda sunulmuştur. O'na göre insan hakları: (i) İnsanların sahip olduğu hürriyetlerdir. (ii) İnsan hakları veya insan hürriyetleri, insanların sahip olduğu serbest hareket etme güçleridir (Gözler, 2017:58-59).

1993 yllında Viyana'da düzenlenen Dünya İnsan Hakları Konferansı'na katılan tüm hükümetler tarafından oybirliğiyle yeniden benimsenen Birleşmiş Milletler doktrini şudur: "Tüm insan haklarl evrensel, bölünemez ve birbirine bağımlı ve birbiriyle ilişkilidir. Uluslararası toplum, insan haklarına küresel olarak adil ve eşit bir şekilde, aynı temelde ve aynı önemle yaklaşmalıdır. Ulusal ve bölgesel özelliklerin ve çeșitli tarihi, kültürel ve dini geçmişlerin önemi göz önünde bulundurulmakla birlikte, siyasi, ekonomik ve kültürel sistemlerinden bağımsız olarak tüm insan haklarını ve temel özgürlükleri teşvik etmek ve korumak devletlerin görevidir." (Viyana Beyannamesi ve Eylem Programı, 1993:5. madde).

İnsan hakları, insanlıkla yașıttır (Bayramoğlu, 2004:131). Ancak insan hakları, özellikle İkinci Dünya Savaşı sonrası yeniden yapılanmanın sağlanması ve şiddetin önlenmesi için bir araç olarak tanımlanmıştır. İnsan haklarl, Avrupa Sözleșmesi'nin giriş bölümünde "dünyada adaletin ve barışın temeli"

6 İnsan hakları kavramı, sadece hukuken değil, aynı zamanda ahlaki ve felsefi ilkeler doğrultusunca tanınması istenilen hakları kapsamaktadır (Gözler, 2017:61). 
ve "etkili siyasi demokrasiye" dayalı olarak devletlerarasında birlik oluşumu olarak adlandırılmaktadır (Wright, 2001:160). Böylece barışı ve güvenliği yeniden tesis etmek için insan haklarına ve temel özgürlüklere saygı gösterecek örgütlerin kurulma süreci hızlanmıştır. Uluslararası insan hakları hukuku da yargı yetkisi altındaki tüm insanların haklarını korumak için devletlere yasal zorunluluklar getirerek, insan insanının bütünlügünü ve haysiyetini korumak amaciyla gelişmiștir (UNDP, 2015:8). İnsan hakları ilk olarak 1945'te Birleşmiş Milletler Şartı ve 1948 Birleşmiş Milletler İnsan Hakları Evrensel Bildirgesi altında uluslararası hukukun önemli bir parçası haline gelmiştir (Wright, 2001:13).

Hakların sağlanması ve sürekliliği amacıyla kabul edilen önemli hukuki metinlerden bazıları; 1978 tarihli Fransız İnsan ve Yurttaş Hakları Bildirgesi, 1948 tarihli Birleşmiş Milletler Insan Haklarl Evrensel Bildirgesi, Avrupa Konseyi tarafından kabul edilen 1950 tarihli Avrupa Insan Hakları Sözleșmesi, Birleşmiş Milletler tarafindan kabul edilen 1966 tarihli Medeni ve Siyasal Haklara İlişkin Uluslararası Sözleşme, 1969 tarihli Amerikan Insan Hakları Sözleşmesi'dir (Gözler, 2017:62). İnsan haklarının sağlanması hususunda Birleşmiş Milletler tarafından 1966 yılında kabul edilen ve 1976 yılında yürürlüğe giren Uluslararası Ekonomik, Sosyal ve Kültürel Haklar Sözleşmesi ise günümüzde 193 üye ülke tarafından imzalanmıştır. Sözleşme kapsamında çalışma koşulları, sosyal güvenlik imkanları, eşit yaşam standartları, eğitim ile sağlık hizmetleri, fiziksel ve ruhsal açıdan en yüksek sağlık standartlarına erişebilme imkanları tanımlanmıştır (Fundar, 2004:20).

İnsan haklarına yönelik Birleşmiş Milletler nezdinde imzalanan diğer sözleşmeler ise 1948

\footnotetext{
${ }^{7}$ Birinci Dünya Savaşı sonunda kimi ülkelerde anayasal düzenlemeler ile sosyal haklar tanınsa da daha çok İkinci Dünya Savașı'ndan sonra sosyal hakların uygulanmaya başlandığı söylenebilir. İkinci Dünya Savașı'ndan sonra istisnasız tüm anayasalarda sosyal haklara yer verilmiştir (Gözler, 2017:103). Bu durum da refah devleti fikrinin zirve yaptığı dönemlerde sosyal haklara daha fazla önem verildiğini açıkça göstermektedir.

${ }^{8}$ Refah devleti (welfare state) ya da Türkçe' de kullanılan ifadeyle sosyal devlet kavramı, emeğin metalaşmasının sınırlandıran ve
}

tarihli Soykırım Suçunun Önlenmesi ve Cezalandırılması Sözleșmesi, 1951 tarihli Mültecilerin Hukuki Durumuna Dair Sözleșme, 1966 tarihli Medeni ve Siyasi Haklara İlişkin Uluslararası Sözleşmesi, 1979 tarihli Kadına Yönelik Her Türlü Ayrımcllığın Önlenmesi Sözleşmesi, 1984 tarihli İşkence ve Diğer Zalimane Gayriinsani veya Küçültücü Muamele veya Cezaya Karşı Birleşmiş Milletler Sözleşmesi, 1989 tarihli Çocuk Haklarına Dair Sözleşme, 1965 tarihli Irksal Ayırımcilı̆ı̆n Önlenmesi Sözleşmesi, 1993 tarihli Ulusal veya Etnik, Dinsel veya Dilsel Azınlıklara Mensup Olan Kişilerin Haklarına Dair Bildiri ve 2006 tarihli Engelli Hakları Sözleşmesi'dir. Devletlerin tüm bu antlaşmalarda tanınan haklara ilişkin yükümlülükleri üç temel kategoriye ayrılmaktadır: Saygı yükümlülüğü, koruma yükümlülüğü ve yerine getirme yükümlülüğüdür (UNDP, 2015:8).

Tarihi süreç incelendiğinde, 1700'lü yılların son döneminde ileri sürülen sosyal haklar doktrini, herkesin insan onuruna yaraşan minimum bir yaşam sürdürebilmesi için devletin çalışma hakkı, adil ücret hakkı, sosyal güvenlik hakkı, öğrenim hakkı, konut hakkı vb. sosyal nitelikli haklara sahip olması gerektiğini benimsemiştir. Böylece devletler, onurlu bir yaşam için gerekli önlemleri almalı ve her vatandaşın haklardan eşit şekilde yararlanması amaciyla mevcut engelleri ortadan kaldırmalıdır (Gözler, 2017:102). ${ }^{7} \quad$ İkinci Dünya Savaşı'ndan sonra ise etkisini giderek arttıran Keynesyen ekonomi politikaları ile refah devleti ${ }^{8}$, büyüme ve genişleme dönemine girmiştir. Böylece bir taraftan tam istihdamın gerçekleşmesi, diğer taraftan da kapsamlı sosyal güvenlik uygulamaları sonucu refah devletinin en önemli amaçlarından biri olarak yoksulluğun önlenmesi kabul edilmiştir. Yine bu dönemde sosyal hizmetler önemini arttırmış

piyasanın olumsuz etkilerinin ortadan kaldırmayı amaçlayan bir rejim olup, ekonomik ve sosyal yaşamı düzenleyen bir takım önlemleri içermekte ve yoksulluğu azaltan sonuçları kapsamaktadır (Şahin Taşğın, 2017:37). Böylece sosyal ihtiyaçları karşılayan, bireylerin yaşam kalitesini yükselten, piyasanın olumsuz etkilerini sınırlandıran, eşitlikçi ve evrensel bir yaklaşımı benimseyen devlet sorumluluğunu ön plana çıkartan bir anlayış söz konusudur (Şahin Taşğın, 2017:80). 
ve yoksullar ile korunmaya muhtaç diğer bireylerin (yaşlı, özürlü, çocuk, kronik sağlık sorunları yaşayanların vb.) insanca onurlu bir yaşam sürdürebilmeleri için insan hakları temelinde, kamusal hizmetlerin sağlanması hedeflenmiştir (Şahin Taşğın, 2017:122-124).

Soğuk Savaş sonrası dönemde demokratikleşme, yerinden yönetim ve yönetimde iyileștirme kavramları değer kazanmıștır. Böylece insan hakları ile ilgili politikalar, makroekonomik düzeyde etkisini daha fazla göstermeye başlamıştır (Hentschel ve Rebhan, 2008:2). Örneğin; Soğuk Savaş sonrası 1990'lı yılların ortalarında Birleșmiş Milletler sistemi içinde UNICEF çocuk ve kadın haklarını güvence altına almak amacıyla Çocuk Hakları Sözleşmesi ile Kadınlara Karşı Her Türlü Ayrımcılığın Önlenmesi Sözleşmesi'nin benimsenmesinde öncülük etmiştir (Alston, 2004:9).

\section{1 İnsan Haklarına Duyarlı Bütçelemenin Teorik Çerçevesi}

18. Yüzyll sonlarından itibaren kamusal finansman, insan haklarının yükselen sesi olma görevi üstlenmiştir (O'Connell, 2013:119). Toplumsal sosyal faydayı maksimum düzeye çlkartmak için kamusal kaynakları doğru bir şekilde kullanmak devletler için önemli bir görevdir (FLAC, 2014:3). Çünkü sivil ve politik hakların devletler tarafından ihlali, sosyal gruplar arasinda artan sosyo-ekonomik eșitsizlikler anlamına gelmektedir (Manion ve diğerleri, 2017:2). Devlet, kabul gören insan hakları yaklaşımına göre hakları ihmal etmemekle beraber, örgüt veya bireylerin insan haklarının ihlal yapmasını engellemekle de yükümlüdürler (Bilgen, 2004:73). Çünkü her zaman, her koşul altında bütün insanların eşit olduklarını sağlamak devletlerin asli görevlerindendir.

2000'li yılların başında Birleşmiş Milletler tarafından insan haklarının sürdürülebilirliğini sağlamak amacıyla Binyıl Kalkınma Hedefleri isimli yeni bir girișim başlatılmıștır. $\mathrm{Bu}$ kapsamda sekiz temel hedefin Birleşmiş Milletlere üye ülkeler tarafından sağlanması amaçlanmaktadır (UNDP, 2015:10). 2002 yılında Birleșmiș Milletler İnsan Hakları Yüksek Komiserliği, binyıl insan hakları hedeflerine ulaşmak için stratejileri ile Binyıl Kalkınma Hedeflerinin birbirini pekiştirdiğini ve tamamladığını hazırladığı bildirmişler. Böylece Binyıl Kalkınma Hedeflerine erişim stratejilerinin insan hakları çerçevesinde faaliyet gösterdiğine vurgu yapılmıştır. Hedefler hem madde hem de süreç açısından insan haklarına sıkı sıkıya bağlıdır (Alston, 2004:7). Çünkü insan hakları ve Binyıl Kalkınma Hedefleri, insan refahını teşvik etmek ve tüm insanların doğuştan gelen onurunu korumak gibi nihai hedefleri içermektedir (UNDP, 2015:10). Binyll Kalkınma Hedefleri arasında aşırı yoksulluğu ve açlığı ortadan kaldırmak, evrensel açıdan ilköğretim hizmetini sağlamak, cinsiyet eşitliğini teşvik etmek ve kadınları güçlendirmek, çocuk ölümlerini azaltmak, anne sağlığını iyileștirmek, HIV/AIDS, sitma ve diğer hastalıklarla mücadele etmek, çevresel sürdürülebilirliği sağlamak ve kalkınma için küresel bir ortaklık geliştirmek yer almaktadır (UNDP, 2015:10).

İnsan hakları ile devlet bütçesi arasındaki ilişki araştırılırken iki süreci göz önünde bulundurmak gereklidir. Öncelikle insan haklarına duyarlı bütçelemenin kapsamı ve niçin önemli olduğu bilinmelidir. İnsan haklarına duyarlı bütçeleme; devlet bütçesinin insan hakları standartlarına ve insan hakları yükümlülüklerine duyarlı olarak hazırlanması ve uygulanmasıdır. Diğer bir ifadeyle; insan haklarının sağlanması için tasarlanmış bir bütçe amaçlanmaktadır (Blyberg, 2015:4). Bu bütçeleme kapsamında kamu kaynaklarının hem sosyo-ekonomik hem de sosyo-kültürel olarak sinıflandırılması hedeflenmektedir. Böylece temel hizmetlerden faydalanamayan vatandaşlara yönelik bütçe tahsisleri sağlanmaktadır (Meriç, 2013:159-160). Çünkü devletler tüm kurum ve uygulamaları ile insan haklarını korumada ve gerçekleştirmede esas rol alan aktörlerdir. Temel insan haklarından mahrum olanların asgari düzeyde de olsa ihtiyaçlarının temini ve haklarının korunması, ayrıca insan haklarının sürdürebilirliğinin 
önünde bir engel olan yoksulluğun çözümü için devlete önemli görevler düşmektedir (Şahin Taşğın, 2017:204).

İnsan haklarına duyarlı bütçeleme sadece eğitim ve sağlık hakları ile değil, aynı zamanda barınma hakkl, su hakkl, yeterli yiyeceğe erişim hakkı, çalışma hakkı ve sosyal güvenlik hakkı vb. pozitif statü haklarını ${ }^{9}$ da içermektedir (GTZ, 2010:2). İnsan haklarına duyarlı bütçelemenin diğer bir ismi sivil topluma duyarlı bütçelemedir. Çünkü bu uygulama sivil toplum kuruluşlarının önem verdiği insani değerleri esas almaktadır (Meriç, 2013:160). Ayrıca insan haklarına duyarlı bütçeleme ile parlamentoları, komisyonları, yerel konseyleri ve denetim kurumlarını bilgilendirmek; bakanlıklarda ve yerel yönetimlerde kamu finansman becerilerini güçlendirmek; sivil toplum örgütlerinin, özellikle de azınlık kesiminin temsil kapasitesinin güçlenmesini desteklemek ve bütçeyle ilgili olarak medya ve kamuya açık oturumlar aracılığıyla eleştirel bir tartışma ortamı yaratmak hedeflenmektedir (German Institute, 2010:4). Bu bütçeleme yaklaşımının diğer faydaları arasında devlet ile vatandaşlar arasındaki mali gücün dengelenmesi, halktan elde edilen gelirlerin yine halka yönelik harcanması, katılımcılığın artması ve hesap verilebilir bir demokratik ortamın teşvik edilmesi yer almaktadır (Meriç, 2013:160).

\section{2 İnsan Haklarına Duyarlı Bütçeleme Analizi}

İnsan hakları ile devlet bütçeleri arasındaki ilişki incelenirken bilinmesi gereken diğer süreç, insan haklarına duyarlı bütçeleme analizidir. Devlet bütçelerinin insan hakları normlarına ve standartlarına uyacak şekilde hazırlanması ve uygulanması yeterli değildir. İnsan haklarına duyarlı bütçeleme analizi özünde haklarla ilişkili belirlenen politikaların ve planların, bütçenin izlenmesi ile değerlendirilmesi süreçleriyle birlikte ele

9 Pozitif statü hakları, vatandaşların devletten müspet bir davranış, hizmet ya da yardım isteme imkânı tanıyan haklar olarak tanımlanmaktadır. Örneğin; çalışma hakkı, sağlık hakkı, konut hakkı, sosyal güvenlik hakkı bu tür haklardan sadece bazılarıdır. Pozitif statü hakları, devlete sosyal bağlamda bir takım ödevler yüklemektedir. $\mathrm{Bu}$ alınması gerektiğini ifade etmektedir. Daha açık bir ifadeyle; ulaşılan sonuçların hedeflerin yüzde kaçını tutturduğunu anlamak ve alınması gereken önlemlerin tespit edilmesinde yardımcı olmaktadır (Blyberg, 2015:4). İnsan haklarına duyarlı bütçeleme analizi, dezavantajlı vatandaşların ihtiyaçlarını karşılamak için stratejiler ve yöntemler geliștirilmesinde katkıda bulunmaktadır. İnsan haklarına duyarlı bütçeleme analizi ekonomik, sosyal ve kültürel hakların geliştirilmesi, izlenmesi, değerlendirilmesi ve savunulması için güçlü bir enstrümandır. Devlet bütçelerini anlamak ve analiz etmek, uluslararası insan hakları yasal yükümlülükleri ve politikaları çerçevesinde hükümetlerin mevcut kaynaklarını azami ölçüde kullanıp kullanmadıklarını belirlemek için önemlidir (Manion ve diğerleri, 2017:2).

İnsan haklarına duyarlı bütçeleme analizi yapılırken izlenmesi gereken adımlar sırasıyla şunlardır: (i) Birleşmiş Milletler tarafından belirlenen hukuki yükümlülükleri dikkate almak, (ii) Bütçe analiz yöntemi belirlemek, (iii) Niceliksel yöntemler belirlemek, (iv) Süreç tanımlaması yapmak ve (v) Önceden yapılmış benzer bütçe analizleri varsa onları da incelemektir (Allen ve diğerleri, 2016:15).

\subsubsection{Birleşmiş Milletler Tarafından Belirlenen Hukuki Yükümlülükler}

Çalışmanın bu başlığı altında sırasıyla maksimum mevcut kaynaklar yükümlülüğü, aşamalı gerçekleştirme yükümlülüğü, durum iyileştirilmesi yükümlülüğü ve minimum çekirdek yükümlülügü hakkında bilgi verilmektedir. Böylece Türkiye'de merkezi yönetim bütçe ödenekleri ve harcamaları analiz edilirken dikkat edilecek yükümlülükler hakkında bilgilendirici açlklamalar yapılmaktadır.

hakların çoğunluğu sosyal ve ekonomik alanlar ile ilişkilidir ve T.C. 1982 Anayasası'nın Sosyal ve Ekonomik Haklar ve Ödevler (41. ve 65. maddeleri arası) başlı̆̆ında açıkça belirtilmektedir. Pozitif statü hakları, sosyal devlet anlayışının bir sonucudur ve bu haklar "sosyal haklar" olarak da bilinmektedir (Gözler, 2000:211). 
İzmir İktisat Dergisi (İzmir Journal of Economics) , Yll: 2019, Cilt:34, Sayı:4, ss. 599-621

\subsubsection{Maksimum Mevcut Kaynaklar Yükümlülüğü}

2007 yllında Birleşmiş Milletler Ekonomik, Sosyal ve Kültürel Haklar Komitesi "İhtiyari Protokol / Seçmeli Protokol uyarinca "Maksimum Mevcut Kaynaklar için Adım Atma Yükümlülüğünün Değerlendirilmesi" isimli bildirinin yayınlanmasiyla maksimum mevcut kaynaklar yükümlülüğü kabul edilmiştir. Böylece Uluslararası Ekonomik, Sosyal ve Kültürel İnsan Hakları Sözleșmesi'ni imzalayan her üye devlet, "Maksimum Mevcut Kaynaklar" (Maximum Available Resources) yükümlülüğünü kabul etmek ve gerekli önlemleri almak zorundadır (United Nations, 2007). İlgili yükümlülüğe göre devlet bütçesi kapsamında insan haklarını desteklemek amacıyla ayrılan ödeneklerin başka alanlarda kullanılması mümkün değildir (Elson ve diğerleri, 2011:16-17). Diğer bir ifadeyle; insan haklarını sağlamak amacıyla ayrılan kaynaklar başka amaçlara yönlendirilmemeli, tahsis edilmemeli veya merkezi hükümete geri verilmemelidir (O'Connell, 2017:88).

\subsubsection{Aşamalı Gerçekleştirme Yükümlülüğü}

İnsan haklarına duyarlı bütçelemeye ilişkin ikinci önemli yükümlülük Aşamalı Gerçekleştirmedir (Progressive Realization). Böylece Uluslararası Ekonomik, Sosyal ve Kültürel İnsan Hakları Sözleşmesi'nin 2. maddesine göre devletler sözleşmede tanınan hakların tam olarak gerçekleștirilmesini sağlamak amacıyla faaliyete geçme yükümlülüğü altındadır (Wright, 2001:75). Diğer bir ifadeyle, aşamalı gerçekleştirme yükümlülüğü ile haklarının sürdürülebilirliği için ilerlemenin kaydedilmesi ve bu kapsamda yöneticilerin acilen ihtiyaç duyulan önlemler almasıdır. Bununla birlikte ileriki zamanlarda hakların etkinliğinin gerçekleşmesine dair bütün faaliyetler bu amaç doğrultusunda değerlendirilmektedir (www.escr-net.org). Bu yükümlülük her türlü ekonomik, sosyal ve kültürel hakların tamamen sağlanmasına yönelik gerekli önlemlerin alınması amacıyla acil bir zorunluluk olarak düşünülmelidir. Kamusal kaynakların eksik olması durumunda ekonomik, sosyal ve kültürel hakların sağlanması için her türlü önlemlerin alınmaması veyahut eylemsizlik durumu akla gelmemelidir (OHRCH, 2008:14; Güngör Göksu, 2018:162-163).

\subsubsection{Durum İyileştirilmesi Yükümlülüğü}

İnsan haklarına duyarlı bütçeleme ile ilgili diğer önemli bir yükümlülük ise Durum İyileștirilmesidir (Non-Regression). $\quad \mathrm{Bu}$ yükümlülük gereğince devletler, güçlü gerekçeleri olmadıkça mevcut hakların kötüleşmesine izin veremezler (PWESCR, 2015:2). Kamu gelir kısitlamaları veya mali tasarruf tedbirleri karşısında bile hakların tam olarak uygulanması amacıyla mümkün olan en yüksek tutarda ödenek tahsis edilmelidir. Kısacası devletlerin ekonomik, sosyal ve kültürel hakların desteklenmesi konusunda belirli ve sürekli bir yükümlülüğü söz bulunmaktadır.

\subsubsection{Minimum Çekirdek Yükümlülüğü}

İnsan haklarına duyarlı bütçeleme ile ilişsili son yükümlülük Minimum Çekirdektir (Minimum Core). Bu yükümlülük kapsamında mevcut hakların her birine ilişskin bir eşik değer belirlenmektedir. Böylece devletler hangi kaynak düzeyinde olursa olsun, kendi yetki alanında yaşayan vatandaşların hepsinin haklarını belirlenen eşik düzeyde koruma altına almak zorundadırlar. Örneğin; açlıktan koruma, temel eğitim, acil sağlık hizmetleri, barınma ihtiyacı ve koruma hizmetleri bireylerin onurlu bir yaşam sürdürebilmeleri için asgari gereklilikler arasında yer almaktadır ve devletler her zaman bu hakları sağlamakla yükümlüdürler (Chapman ve Russell, 2002).

\subsection{Bütçe Analiz Yöntemleri}

İnsan haklarına duyarlı bütçeleme analizi yapılırken ikinci adım uygun bütçe analiz yöntemini belirlemektir. İlgili analiz yöntemleri üç gruba ayrılmaktadır. Birinci analiz yöntemi gelir odaklı analizdir (Gelir elde etme biçimi). İkinci analiz yöntemi bütçe ödeneklerinin tahsisi analizidir (Bütçede ödenekler nasıl dağıtılır?). Son analiz yöntemi ise bütçe harcamaları analizidir (Tahsis edilen ödeneklerin harcanması) (Manion ve diğerleri, 2017:6). 
Gelir odaklı analiz yönteminde, hükümetlerin vergilendirme yetkileri üzerine odaklanılmakta ve kamu gelirleri incelenmektedir (Allen ve diğerleri, 2016:10). Bütçe ödeneklerinin tahsisi analizleri kapsamında ise araştırmacılar, hükümetlerin yükümlülüklerini yerine getirip getirmediğini tespit etmek amaciyla harcama modellerini karşılaştırmaktadırlar. Kamu harcama analizinde de mevcut harcamalar ve bütçe ödenek tahsisleri arasındaki ilişki ele alınmaktadır (Elson, 2006:24). Kamu harcamaları analizinde haklara yönelik merkezi bütçeden ayrılan paylar ile bunların GSYH içerisindeki payları esas alınmaktadır (Elson, Radhika ve Heintz, 2011:22). Kamu harcama analizi kapsamında bütçe ödenekleri ile gerçekleşen harcama tutarları karşılaştırılmaktadır (Elson, 2006:24).

\subsection{Niceliksel Verilerin Kullanımı}

İnsan haklarına duyarlı bütçeleme analizi yapılırken sayısal veriler dört şekilde analize dahil edilebilir (Allen ve diğerleri, 2016:11-12):

> Uluslararası Karşılaştırmalı Bütçe Analizi: Bir ülkenin belirli bir alandaki gelirleri ya da harcamaları ile başka ülkelerin aynı alanlarındaki gelirleri ya da harcamaları karşılaștırılmaktadır.

> Ulusal Düzeyde Bütçe Analizi: Ulusal düzeyde kamu gelirleri, harcamaları ve bütçe ödenekleri incelenmektedir.

$>$ Yerel Yönetim Düzeyinde Bütçe Analizi: İki yerel yönetim arasında karşılaştırma yapmak amaciyla veriler incelenmektedir.

Sektörler Arası Karşılaştırmalı Bütçe Analizi: Sektörler arası bütçe analizi yapılırken kamu gelirleri ile giderleri karşılaştırılmaktadır.

\subsection{Süreç Tanımlaması}

İnsan haklarına duyarlı bütçeleme analizleri zaman sınırlaması açısından iki şekilde yapılabilmektedir. Birinci süreç tanımlaması statik analizdir. Statik analiz açısından devlet bütçesi sadece belirli bir döneme ilişkin olarak analiz edilmektedir. İkinci süreç tanımlaması ise dinamik analizdir. Bu aşamada mevcut yıl bütçesi, geçmiş yı bütçeleri ile klyaslanmaktadır. Dinamik analiz, özellikle mevcut kaynakların maksimum kullanımına yönelik insan haklarına ilişkin alınan kararlarda devletlerin yükümlülüklerini ne ölçüde yerine getirdiğini belirlemek ve değerlendirmek açısından önemlidir (OHCHR, 2009:13).

\section{MERKEZI YÖNETIM BÜTÇE ÖDENEKLERININ VE HARCAMALARININ İNSAN HAKLARINA DUYARLI BÜTÇELEME AÇISINDAN ANALIZII}

Çalışmanın bu başlığı altında, merkezi yönetim bütçesi kapsamında yer alan bütçe ödenekleri ile harcamaları verileri kullanılarak insan haklarına duyarlı bütçelemeye ilişkin bir analiz yapılmaktadır.

Tablo 1. 1982 Anayasasinda Yer Alan Ekonomik, Sosyal ve Kültürel Haklara İlişkin Hükümler

\begin{tabular}{|c|c|}
\hline Birinci Kısım: Genel & $\begin{array}{l}\text { II. Cumhuriyetin nitelikleri } \\
\text { (Madde 2) }\end{array}$ \\
\hline Esaslar & $\begin{array}{l}\text { V. Devletin temel amaç ve } \\
\text { görevleri (Madde 5) }\end{array}$ \\
\hline $\begin{array}{l}\text { İkinci Bölüm: Kişinin } \\
\text { Hakları ve Ödevleri }\end{array}$ & XII. Mülkiyet hakkı (Madde 35) \\
\hline $\begin{array}{c}\text { Üçüncü Bölüm: Sosyal } \\
\text { ve Ekonomik Haklar ve } \\
\text { Ödevler }\end{array}$ & $\begin{array}{l}\text { I. Ailenin korunması ve çocuk } \\
\text { hakları (Madde 41) } \\
\text { II. Eğitim ve ögrenim hakkı ve } \\
\text { ödevi (Madde 42) } \\
\text { III. Kamu yararı (Madde 43, Madde } \\
\text { 44, Madde 45, Madde 46 ve Madde } \\
\text { 47) } \\
\text { IV. Çalışma ve sözleşme hürriyeti } \\
\text { (Madde 48) } \\
\text { V. CCalışma ile ilgili hükümler } \\
\text { (Madde 49, Madde 50, Madde 51, } \\
\text { Madde 52, Madde 53 ve Madde 54) } \\
\text { VII. Ücrette adalet sağlanması } \\
\text { (Madde 55) } \\
\text { VIII. Sağllk, çevre ve konut (Madde } \\
\text { 56 ve Madde 57) } \\
\text { IX. Gençlik ve spor (Madde 58 ve } \\
\text { Madde 59) } \\
\text { X. Sosyal güvenlik hakları (Madde } \\
60, \text { Madde 61 ve Madde 62) } \\
\text { XI. Tarih, kültür ve tabiat } \\
\text { varlıklarının korunması (Madde } \\
\text { 63) } \\
\text { XII. Sanatın ve sanatçının } \\
\text { korunması (Madde 64) } \\
\text { XIII. Devletin iktisadî ve sosyal } \\
\text { ödevlerinin sınırları (Madde 66) }\end{array}$ \\
\hline
\end{tabular}

Kaynak: T.C. 1982 Anayasası, Resmi Gazete 9/11/1982 tarih ve Sayı:17863. 
Sayısal verilerin incelenmesine geçmeden önce T.C. 1982 Anayasasında yer alan ekonomik, sosyal ve kültürel haklara ilişkin hükümler açıklanacaktır. Tablo 1 incelendiğinde, T.C. 1982 Anayasasinda yer alan toplam 28 maddenin ekonomik, sosyal ve kültürel haklar ile doğrudan ilişkili olduğu anlaşılmaktadır.

3.1 Türkiye'de Toplumsal İhtiyaçlara Yönelik Sosyal Nitelikli Kamu Harcamalarını İnceleyen Çalışmaların İncelenmesi

5018 sayılı KMYKK kabulü ile 2006 yılından itibaren Genel Yönetim kapsamına giren bütün kamu idareleri bütçelerini analitik bütçe sınıflandırmasına göre hazırlamaktadırlar. Analitik bütçe sınıflandırmasının fonksiyonel sınıflandırma bölümü kamu harcamalarının hangi amaçları gerçekleştirmeye yönelik yapıldığını açıklamakta kullanılmaktadır. Böylece eğitim, sağlık, sosyal güvenlik ve yardım, adalet vb. pozitif toplumsal niteliği yüksek kamu harcamalarını takip etmek mümkündür (Kayalıdere ve Şahin, 2014:64). $\mathrm{Bu}$ alt başlık kapsamında Türk maliye literatüründe sosyal pozitif dışsallık taşıyan kamu harcamalarına ilişkin daha önce yapılmış çalıșmalar araştırılmıștır.

Toprak ve diğerlerinin 2002-2015 ylları arasında eğitim harcamalarını incelediği çalışmalarında, toplam kamu eğitim harcamalarının merkezi yönetim bütçesine oranı 2015 yılı için \%16,5 olduğu raporlanmıştır. Ayrıca Milli Eğitim Bakanlığının GSYH' dan 2002 yılında aldığı pay \%2,13 iken, 2014 yılında bu oran \%3,24'e yükseldiği vurgulanmıștır (Toprak ve diğerleri, 2016:162). Başka bir çalıșmada ise YÖK bütçesinin GSYH oranının \%1'in altında seyrettiği ve genel bütçe içerisinde ise \%2-4 aralığında gerçekleştiği sonucuna varılmıştır. YURTKUR bütçesinin payı ise MEB ve YÖK bütçelerine kıyasla oldukça düşük kaldığı tespiti yapılmıștır (Güngör ve Göksu, 2013:66).

Sağlık harcamaları açısından bir değerlendirme yapılırsa, toplam sağlık harcamalarının GSYH'ye oranı 1999 yllında \%4,8 iken, 2007 yılında \%6'ya yükseldiği görülmektedir.
Bununla birlikte 2007 yılı için gerçekleșen \%6'lık oran, Türkiye'de kişi başına düşen sağlık harcamasının orta gelirli ülkelerin yaklaşık üç katı düzeyinde gerçekleştiği anlamına gelmektedir (Çelik, 2011:64-68). 2016 yılında ise bu oran \%4,6 olarak gerçekleşmiştir. Ayrıca 2016 yılında cari sağlık harcamaları içerisinde genel devlet sağlık harcamalarının oranı $\% 78,4$ ve özel sektör sağlık harcamalarının oranı \%21,6 olarak gerçekleşmiştir (Ağır ve Tıraş, 2018:648-652).

Türkiye'de sadece sosyal koruma harcamaları 2000'li yılların bașında \%5-6 iken, bu oran 2013 yılında \%10 dolayındadır (Kayalıdere ve Şahin, 2014:64-66). Başka bir çalışmada ise sosyal güvenlik ve sosyal yardım harcamalarının GSYH içerisindeki payı incelenmiş ve 2013 yılında bu oran \%12,71 olarak raporlanmıştır. Aynı hizmet türünün toplam kamu harcamaları içerisinde payı ise 2013 yılında \%33,5 olarak gerçekleşmiştir (Ataer ve Efe, 2016:94-95).

Toplumsal cinsiyet eşitliğini sağlamak amacıyla Kadının Statüsü Genel Müdürlüğü, TBMM Kadın-Erkek Fırsat Eşitliği Komisyonu ve Toplumsal Cinsiyete Duyarlı Bütçeleme (TCDB) Alt Komisyonu tarafından çalışmalar yürütülmektedir (Yıldız ve Uğur, 2016:291). Türkiye'de 2008 yılından itibaren öncelikle İçişleri Bakanlığı ile ortaklaşa TCDB ile ilgili toplantılar yapılmış, etkinlikler desteklemiş, ortak projeler gerçekleşmiş ve son dönemlerde pilot kent belediyelerinde yoğunlaşan eğitim etkinlikleri hızlanmıștır (Günlük Şenesen ve diğerleri, 2017: 8). Onuncu Kalkınma Planı (2014-2018) kapsamında "Toplumsal cinsiyete duyarlı bütçeleme konusunda farkındalık olușturulacak ve örnek uygulamalar geliștirilecektir." hedefi yer almıștır (Kalkınma Bakanlığı, 2013:41). 11. Kalkınma Planı'nda (2019-2023) ise "Güçlü toplumun inşası kadınların güçlenmesiyle mümkün olacaktır. $B u$ bağlamda, kız çocuklarının ve kadınların eğitim ve öğrenime erişimi ile sosyal ve ekonomik hayata katılıminın artırılması, kaynaklara erişimin kolaylaştırılması, kadının toplum içindeki statüsünün geliştirilmesi için 
farkındalı̆̆ın artırılmasına yönelik çalışmalar yapılacaktır" hedefi konulmuștur. Bu kapsamda belirlenen 2023 hedeflerinden bazıları şunlardır: (i) Kadınların işgücüne katılım oranı 2018 yılı için gerçekleşen 34,2 iken, 2023 yılında 38,5'e, (ii) Parlamentoda temsil oranı 2018 yılı için \%17,3'ten 2023 yılı için \%20'ye, (iii) Kadın istihdam oranı \%29'dan 2023 yılı için \%34'e ve (iv) Yükseköğretimde kadın okullaşma oranının \%47,4'ten \%60'a çıkartılması hedeflenmektedir (Strateji ve Bütçe Başkanlığı, 2018:152).

Adalet harcamaları açısından durum değerlendirilmesi yapilırsa, Adalet Bakanlığının ödeneklerinin merkezi yönetim bütçesi içerisindeki payı 2006 yılında \%0.97 iken, 2016'da \%1.67'ye ulaşmıştır. Ayrıca Adalet Bakanlığının 2010-2016 dönemine ilişkin fonksiyonel sınıflandırmaya göre ödenek ve harcamaları içerisinde en yüksek payı kamu düzeni ve güvenlik hizmetleri almıştır. $\mathrm{Bu}$ hizmet kaleminin toplam ödenek ve harcamalara oranı ortalama \%81 dolayında gerçekleşmiştir (Egeli ve Atılgan Yasa, 2017:8991).

\subsection{Fonksiyonel Sinıflandırma Kapsamında Ekonomik, Sosyal ve Kültürel Haklara İlişkin Bütçe Kalemlerinin Belirlenmesi}

5018 sayılı Kamu Mali Yönetimi ve Kontrol Kanunu'nun kabul edilmesinden sonra kamu harcamalarının idari, ekonomik ve fonksiyonel sınıflandırmaya tabi tutulması ve yeni bir bütçe kod sisteminin oluşturulması amaçlanmıştır. Kamu idarelerinin hangi hizmete türüne yönelik ne kadar tutarda harcama yaptığının kolayca ve detaylı bir şekilde takibi açısından da analitik bütçe sınıflandırması oluşturulmuştur. Böylece, merkezi yönetim bütçesi kapsamındaki tüm kurumlarda bütçe sınıflandırması standart hale getirilmiştir (BÜMKO, 2018).

Fonksiyonel sınıflandırmada kamu harcamaları kapsamında tam kamusal mal ve hizmet niteliği ağırlıklı olan devletlerin ana görevleri dıșında yer alan yaşam kalitesine yönelik harcamalar, sosyal harcama olarak bilinmektedir. Bu bilgiye istinaden çalışmada insan haklarına yönelik bütçe kalemleri belirlenirken fonksiyonel sınıflandırmanın kullanılması tercih edilmiştir. Çünkü fonksiyonel sınıflandırma kapsamında devlet faaliyetlerinin türleri gösterilmekte, bu faaliyetlere yönelik bütçe ödenek tahsisleri ile gerçekleşen harcamaların belirli bir dönemde izlenmesine ve uluslararası karşılaştırma yapılmasına imkân sağlanmaktadır. Bununla birlikte fonksiyonel sınıflandırma ile sektörel farklılaşmanın yapılabilmesi de kolaylaşmaktadır.

Tablo 2'de fonksiyonel sinıflandırma esas alınarak, merkezi yönetim kamu harcamaları kapsamında insan hakları ile ilişkili bütçe kalemleri belirlenmeye çalışılmıştır. Bütçe kalemlerinin insan hakları ile ilişkisi belirlenirken, kamu hizmet türünün sosyal fayda içerip içermediğine ve topluma taşan seviyede pozitif dışsallık taşıyıp taşımadığına bakılmıştır. Tablodan da anlaşılacağı üzere, "Genel Kamu Hizmetleri ile "Ekonomik İșler ve Hizmetleri" birinci düzey sinıflandırmaların sosyal faydalarının diğer hizmet türlerine klyasla oldukça düşük olduğu anlaşılmaktadır. Oysaki insan hakları ile ilişkili bir bütçeden bahsediliyorsa, analiz edilecek bütçe kalemlerinin özellikle sosyal fayda içermesi çok önemlidir. Bu sebeple bu iki hizmet türüne ait sayısal veriler analiz dışı bırakılacaktır. Ayrıca savunma hizmetinin ikinci düzey sınıflandırmasının alt kalemleri incelendiğinde, sadece sivil savunma harcamalarının değerlendirmeye alınması uygun görülmüştür. Diğer birinci düzey hizmet türlerinin hepsinin yüksek düzeyde sosyal fayda yaydığı ve özellikle insan haklarını desteklemek amacıyla yüksek öneme sahip oldukları kanaatine varılmıştır. Böylece toplamda 48 adet ikinci düzey hizmet türüne ait sayısal verilerin analiz edilmesi sonucuna varılmıştır.

\subsection{Ekonomik, Sosyal ve Kültürel Haklar İle İlişkili Bütçe Kalemlerinin İncelenmesi}

İnsan haklarına duyarlı bütçeleme analizi yapılırken sayısal veriler üç farklı şekilde kullanılmaktadır. 
Tablo 2. Fonksiyonel Sınıflandırma Çerçevesinde İnsan Hakları İle ilişkili Bütçe Kalemleri

\begin{tabular}{|c|c|}
\hline Birinci Düzey & İnsan Haklarını İçeren İkinci Düzey Alt Hizmetler \\
\hline Genel Kamu Hizmetleri & $\begin{array}{l}\text { Genel kamu hizmetleri kapsamına giren kamu harcamalarının sosyal niteliği düşük olduğu için } \\
\text { değerlendirmeye alınmamıştır. }\end{array}$ \\
\hline Savunma Hizmetleri & 1.Sivil Savunma Hizmetleri ${ }^{10}$ \\
\hline Kamu Düzeni ve Güvenlik Hizmetleri & $\begin{array}{l}\text { 2.Güvenlik hizmetleri } \\
\text { 3.Yangından korunma hizmetleri } \\
\text { 4.Mahkeme hizmetleri } \\
\text { 5.Cezaevi idaresi hizmetleri } \\
\text { 6.Kamu düzeni ve güvenliğe ilişkin araştırma ve geliştirme hizmetleri } \\
\text { 7.Sınıflandırmaya girmeyen kamu düzeni ve güvenlik hizmetleri }\end{array}$ \\
\hline Ekonomik İşler ve Hizmetler & $\begin{array}{l}\text { Bu hizmetlerin sosyal açıdan taşıdıkları özellikler zayıftır.11 } \mathrm{Bu} \text { sebeple değerlendirmeye } \\
\text { alınmamıștır. }\end{array}$ \\
\hline Çevre Koruma Hizmetleri & $\begin{array}{l}\text { 8.Atık yönetimi hizmetleri } \\
\text { 9.Atık su yönetimi hizmetleri } \\
\text { 10.Kirliliğin azaltılması hizmetleri } \\
\text { 11.Doğal ortamın ve bio çeşitliliğin korunması } \\
\text { 12.Çevre korumaya iliş̧kin araştırma ve geliştirme hizmetleri } \\
\text { 13.Sınıflandırmaya girmeyen çevre koruma hizmetleri }\end{array}$ \\
\hline $\begin{array}{l}\text { İskan ve Toplum Refahı } \\
\text { Hizmetleri }\end{array}$ & $\begin{array}{l}\text { 14.İskan işleri ve hizmetleri } \\
\text { 15.Toplum refahı hizmetleri } \\
\text { 16.Su temini işleri ve hizmetleri } \\
\text { 17.Sokak ve caddelerin aydınlatılması hizmetleri } \\
\text { 18.İskan ve toplum refahına ilişkin araştırma ve geliştirme hizmetleri } \\
\text { 19.Sınıflandırmaya girmeyen iskan ve toplum refahı hizmetleri }\end{array}$ \\
\hline Sağlık Hizmetleri & $\begin{array}{l}\text { 20.Tıbbi ürünler, cihaz ve ekipmanlara ilişkin işler ve hizmetler } \\
\text { 21.Ayakta yürütülen tedavi hizmetleri } \\
\text { 22.Hastane işleri ve hizmetleri } \\
\text { 23.Halk sağlığı hizmetleri } \\
\text { 24.Sağlık hizmetlerine ilişkin araştırma ve geliştirme hizmetleri } \\
\text { 25.Sınıflandırmaya girmeyen sağlı hizmetleri }\end{array}$ \\
\hline Dinlenme, Kültür ve Din Hizmetleri & $\begin{array}{l}\text { 26.Dinlenme ve spor hizmetleri } \\
\text { 27.Kültür hizmetleri } \\
\text { 28.Yayın ve yayım hizmetleri } \\
\text { 29.Din hizmetleri } \\
\text { 30.Dinlenme kültür ve din hizmetlerine ilişkin araştırma ve geliştirme hizmetleri } \\
\text { 31.Sınıflandırmaya girmeyen dinlenme, kültür ve din hizmetleri }\end{array}$ \\
\hline Eğitim Hizmetleri & $\begin{array}{l}\text { 32.0kul öncesi eğitim ve ilköğretim hizmetleri } \\
\text { 33.Ortaögretim hizmetleri } \\
\text { 34.Ortaöğretim sonrası mesleki eğitim hizmetleri } \\
\text { 35.Yükseköğretim hizmetleri } \\
\text { 36.Seviyeye göre sınıflandırılamayan eğitim hizmetleri } \\
\text { 37.Eğitime yardımcı hizmetler } \\
\text { 38.Eğitime ilişkin araştırma ve geliştirme hizmetleri } \\
\text { 39.Sinıflandırmaya girmeyen eğitim hizmetleri }\end{array}$ \\
\hline $\begin{array}{l}\text { Sosyal Güvenlik ve Sosyal Yardım } \\
\text { Hizmetleri }\end{array}$ & 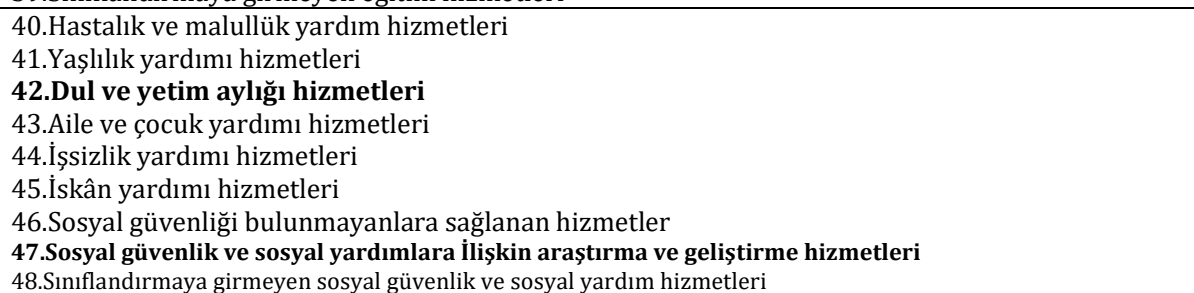 \\
\hline
\end{tabular}

Kaynak: BÜMKO, www.bumko.gov.tr, 31.05.2018.

Bunlardan birincisi, araştırılan bütçe harcamalarının toplam nüfusa oranıdır. ödeneklerinin ya da kamu harcamalarının Üçüncüsü ise araştırılan bütçe ödeneklerinin ya toplam bütçe içerisindeki payıdır. İkincisi, da kamu harcamalarının bir önceki yıla göre araştırılan bütçe ödeneklerinin ya da kamu değişim oranının hesaplanmasıdır (Allen ve

${ }^{10}$ Savunma hizmetleri kapsamında sivil savunma hariç, diğer ulusal savunmaya ayrılan kalemler topluma taşan seviyede dışsallık taşımamaktadır. Ayrıca günlük yașam üzerinde de kısmen bir etkiye sahiptir. Bu sebeple değerlendirmeye alınmamıștır (Erdoğdu, 2013:85).

${ }^{11}$ Fonksiyonel sınıflandırmanın ikinci düzeyi açısından incelendiğinde Ekonomik İşler ve Hizmetler: (i) Genel Ekonomik İşler ve Hizmetler, (ii) Tarım, Ormancılık, Balıkçlık ve Avcılık Hizmetleri, (iii) Yakıt ve Enerji Hizmetleri, (iv) Madencilik, İmalat ve İnșaat Hizmetleri, (v) Ulaștırma Hizmetleri, (vi) İletişim Hizmetleri, (vii) Diğer Endüstriler, (viii) Ekonomik Faaliyetlere İliş̧in Araştırma ve Geliştirme Hizmetleri, (xi) Sınıflandırmaya Girmeyen Ekonomik İşler ve Hizmetlerden oluştuğu görülmektedir. Ekonomik işler ve hizmetler kapsamına giren kamu harcamalarının sosyal niteliği düşüktür ve daha çok özel nitelikleri ağır basmaktadır. Ayrıca bu faaliyet türünün fiyatlandırılması da mümkündür (Erdoğdu, 2013:85). 
diğerleri, 2016:22-23). Tablo 2'de gösterilen 18. 30. 34. 42. ve 36. siradaki alt hizmet türlerine ait veriler ilgili yıllarda BÜMKO tarafından hesaplanmamıștır. $\mathrm{Bu}$ sebeple analizlere toplam 43 adet ikinci düzey hizmet türü ile devam edilmiştir. Çalışmada ele alınan veriler öncelikle maksimum mevcut kaynaklar yükümlülügü

çerçevesince değerlendirilmektedir. $\mathrm{Bu}$ nedenle ilk olarak bütçe ödeneklerinin gerçekleșen harcamalara oranı incelenmektedir.

Tablo 3 incelendiğinde ulaşılan ilk sonuca göre; gerçekleşen kamu harcamalarının çoğunda başlangıç bütçe ödenek tutarlarının \%90 ve üstü olacak şekilde harcandığ anlaşılmaktadır.12 Bazı hizmet türlerinde gerçekleşen harcama tutarları, başlangıçta taahhüt edilenden kat ve kat fazla olmuştur. Örneğin; toplum refahı hizmetleri kapsamında 2006, 2007 ve 2008 yılları analiz edildiğinde, gerçekleșen kamu harcamalarının bütçe ödeneklerine oranı \%360'dan daha fazladır. Bu sonuç, başlangıçta belirlenen bütçe ödeneklerinden 3,6 kat daha fazla kamu harcaması yapılması anlamına gelmektedir. Sınıflandırmaya girmeyen sağlık hizmet türünde 2008 ve 2009 yılında gerçekleşen harcamaların bütçe ödeneklerine oranı \%700 civarındadır. Diğer bir ifadeyle; bu hizmet türünde başlangıç bütçe ödeneklerinin yedi kat fazlası harcanmıştır. 13 yıllık süreçte yaşanan değişimi daha net anlayabilmek amaciyla son sütunda ortalamalara yer verilmiştir.

13 yıllık ortalama esas alındığında, 43 hizmet türünün 27'sinde gerçekleșen harcamaların başlangıç bütçe ödeneklerinden daha fazla olduğu görülmektedir. Hatta bu 27 hizmet türünün $15^{\prime}$ inde harcamalar, başlangıç ödeneklerinin \%110'undan daha fazla gerçekleşmiştir. Maksimum mevcut kaynaklar yükümlülüğü çerçevesinde değerlendirildiğinde ise bu sonuç istenilendir. Çünkü insan haklarını sağlamak amacıyla ayrılan kaynakların başka alanlarda kullanılması mümkün değildir. Diğer bir ifadeyle; harcamaların başlangıç ödeneklerine oranı \%100 ve üzeri olmalıdır.

Fonksiyonel sinıflandırmanın birinci düzey hizmet türleri esas alınarak bir değerlendirme yapılırsa, (i) Sosyal güvenlik ve sosyal yardım hizmetleri, (ii) Eğitim hizmetleri, (iii) Kültür ve din hizmetleri, (vi) İskân ve toplum refahı hizmetleri ve (v) Sağlık hizmetlerinin ikinci düzeylerinin çoğunda gerçekleşen kamu harcamaları, başlangıç bütçe ödeneklerinden fazla olmuştur. Ancak çevre koruma hizmetlerinin kapsamında, "Kirliliğin Azaltılması Hizmetleri" hariç diğer ikinci hizmet türlerinde yılsonu harcamalarının başlangıç ödeneklerine oranı \%100'den daha az gerçekleşmiştir.

Maksimum mevcut kaynaklar yükümlülüğü gereği insan haklarını sağlamak amacıyla kaynaklar mümkün olduğunca en üst limitte kullanılmasına rağmen, bir hizmet türüne ayrılan kamusal kaynakların başka alanlara kullanılması söz konusu olamaz. Bu sebeple Tablo 3'te hesaplanan bulgularin \%100'den daha az olduğu yıllarda incelenen hizmet türüne yönelik maksimum mevcut kaynaklar yükümlülüğünün göz ardı edildiği ifade edilebilir. Genel bir değerlendirme yapıldığında ise; 2006-2018 döneminde toplumsal sosyal faydayı arttırmak ve insan haklarını desteklemek amacıyla yapılan kamu harcamalarının çoğunda Birleşmiş Milletler tarafından belirlenen ve üye ülkelerin uymak zorunda oldukları maksimum mevcut kaynaklar ilkesine uyulduğu anlaşılmıştır.

Tablo 4'te 2007-2018 yılları arasında insan hakları ile ilişkili kamu harcamalarının merkezi yönetim bütçesi içerisindeki artış oranları incelenmektedir. Böylece aşamalı gerçekleştirme ve durum iyileştirme yükümlülüklerine ne kadar uyulduğunun tespit edilmesi hedeflenmektedir. Tablo 4'te özellikle verilerin TL tutarı cinsinden ziyade, oransal olarak gösterilmesinin sebebi; reel sonuçlara

12 Ek 1 ve Ek 2 kısmında incelenen yıllara ait tutarlar verilmiştir. 
İzmir İktisat Dergisi (İzmir Journal of Economics) , Yll: 2019, Cilt:34, Sayı:4, ss. 599-621

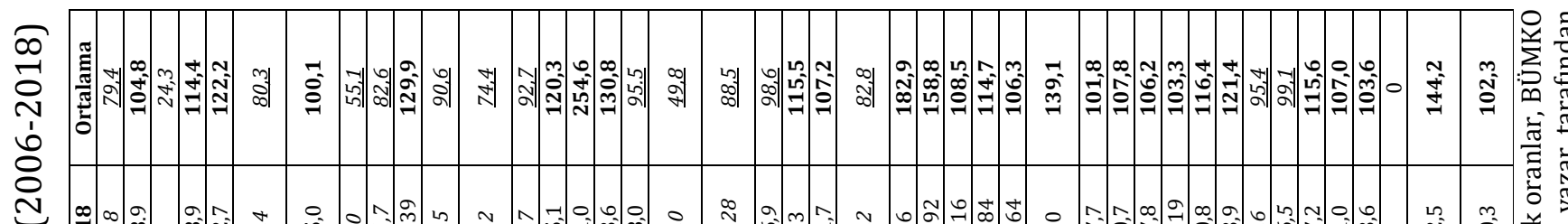

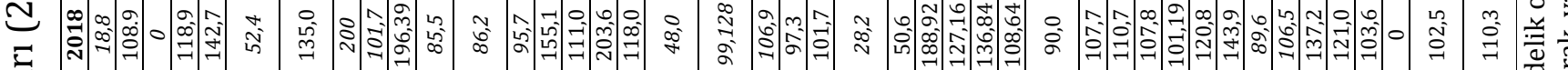

$\frac{\pi}{\pi}$

$\stackrel{5}{6}$

m)

$\frac{\frac{1}{0}}{\frac{1}{0}}$

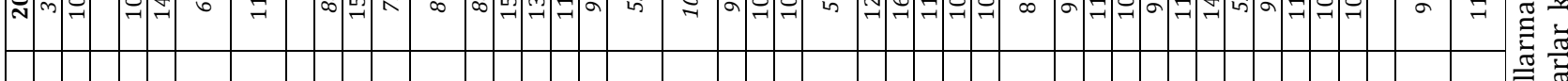

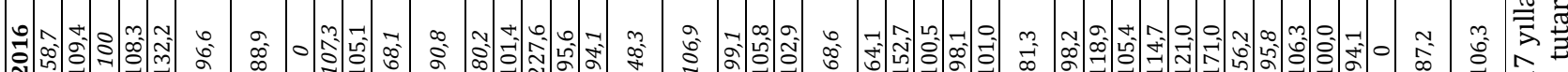

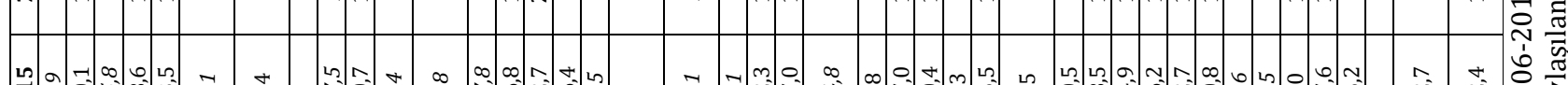

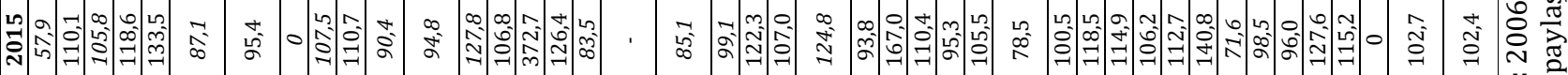

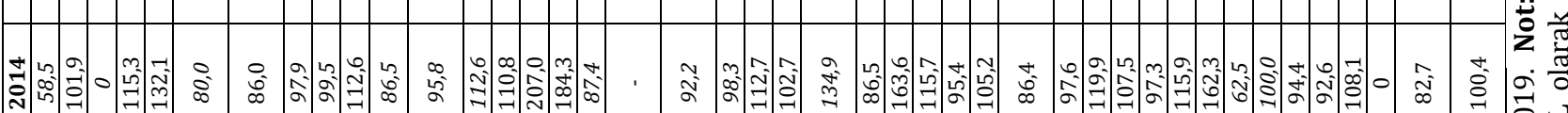

索

ฮี

สิ

(ี

$\frac{1}{4}$

ขับ

寄

כִ

菂

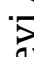

:?

: 

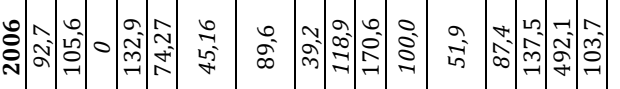

A.

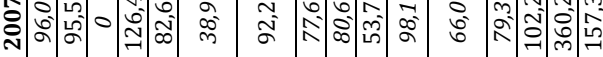

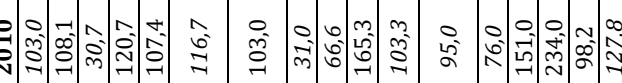

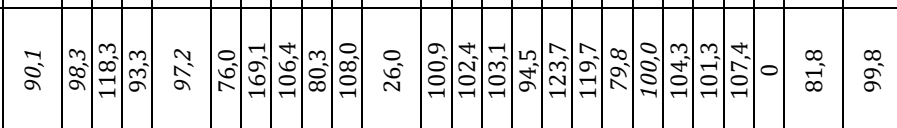

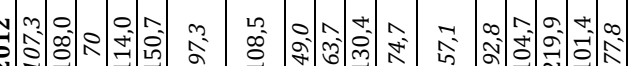

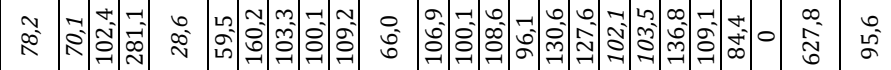
กิ ำ

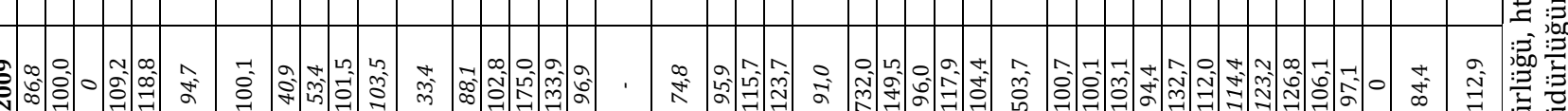

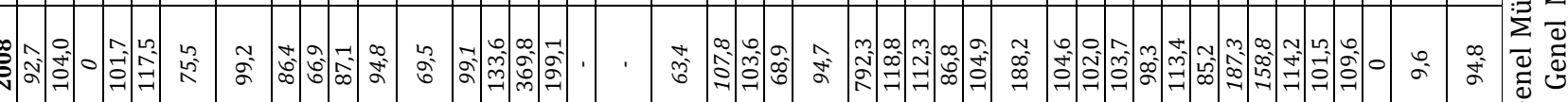

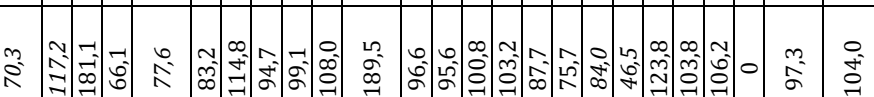
莡 兽 $\stackrel{\overbrace{}}{\Xi}$

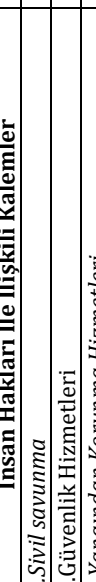
(1)

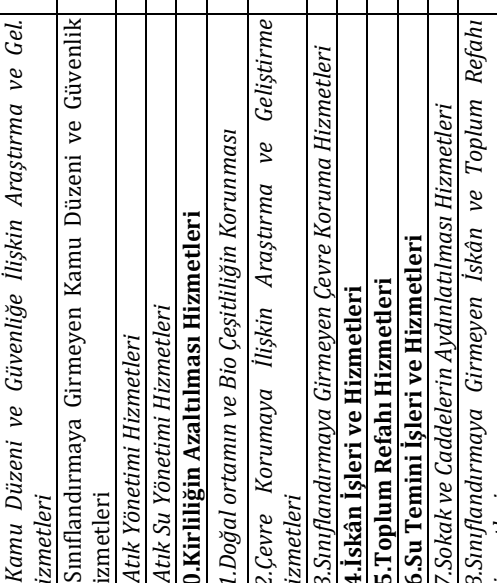

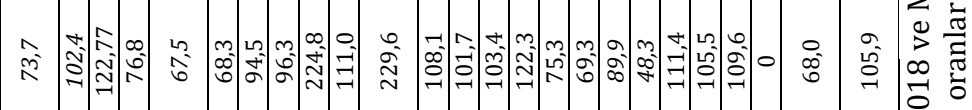

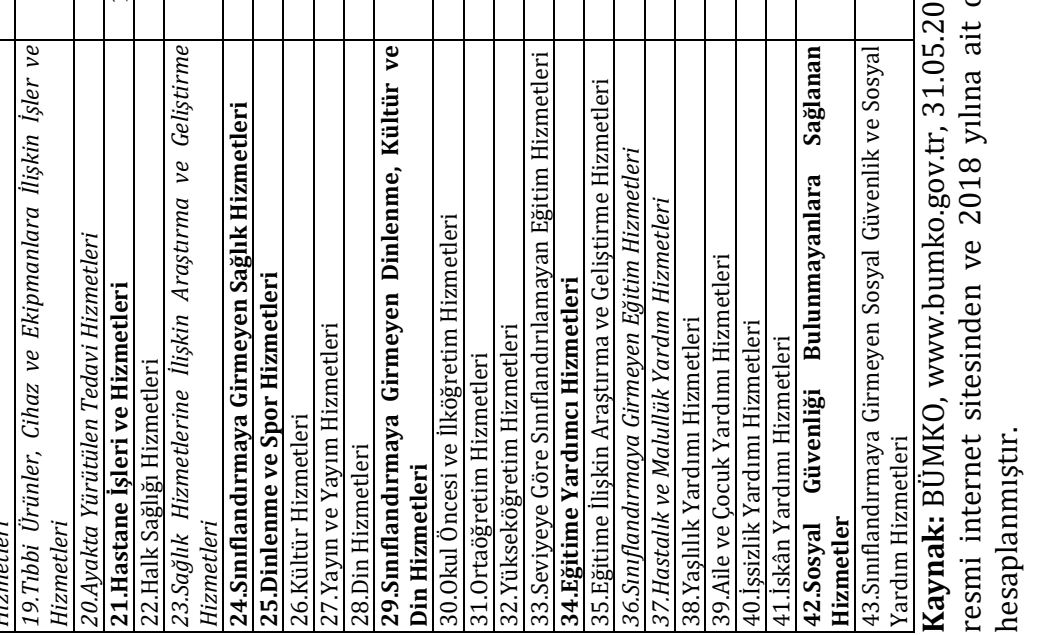




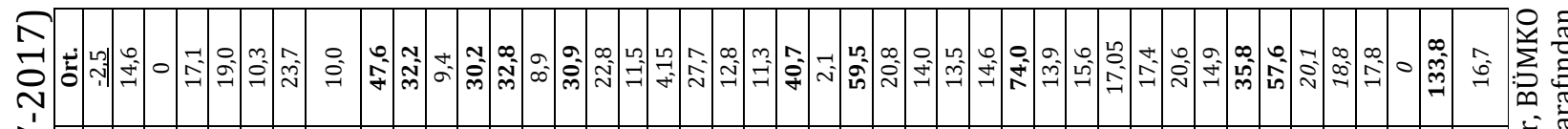

옹

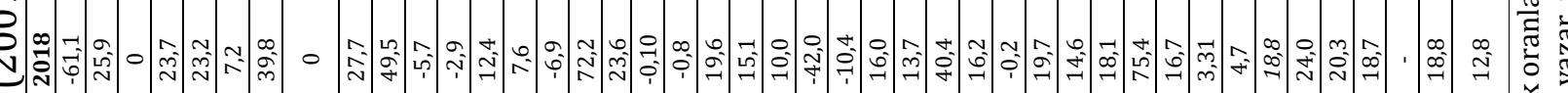
萦

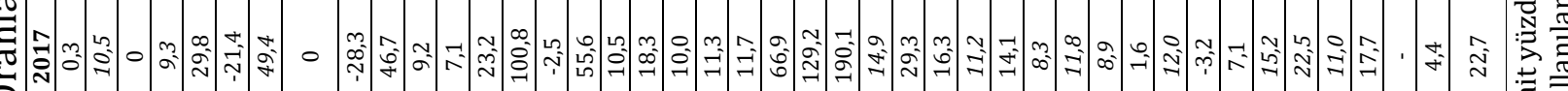

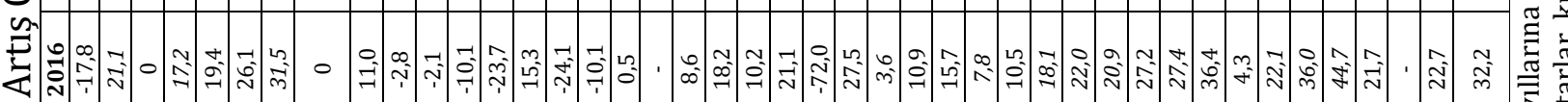
D.

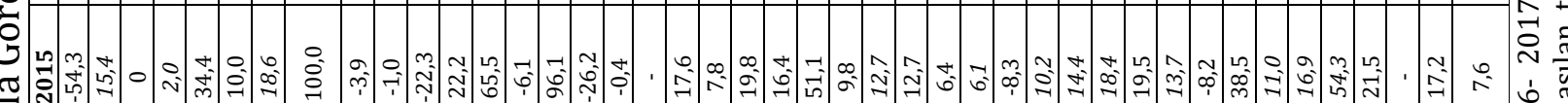

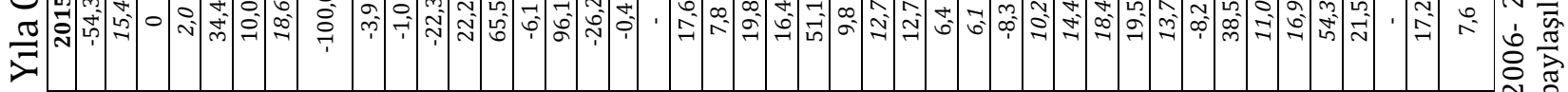

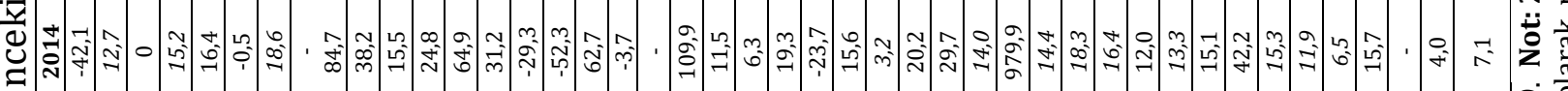

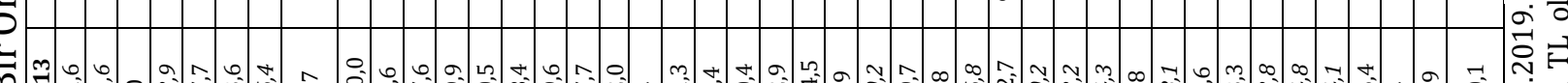

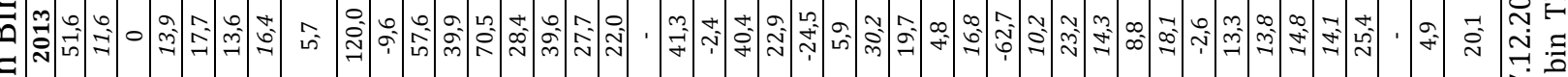

节

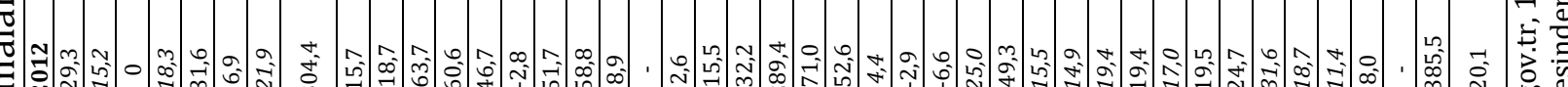

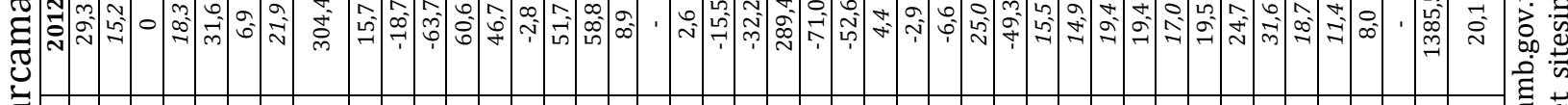

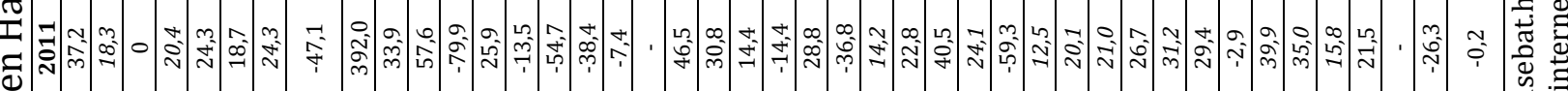

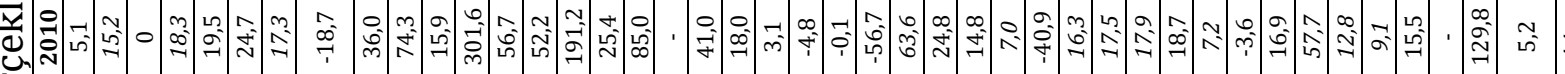

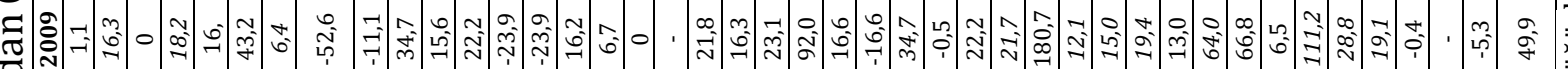
总: :

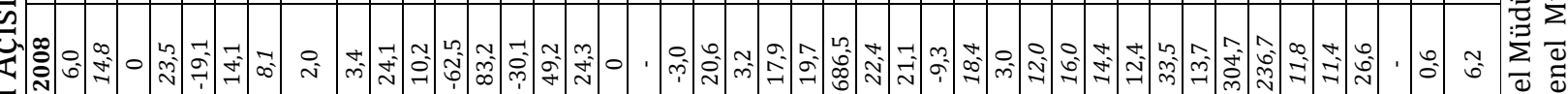

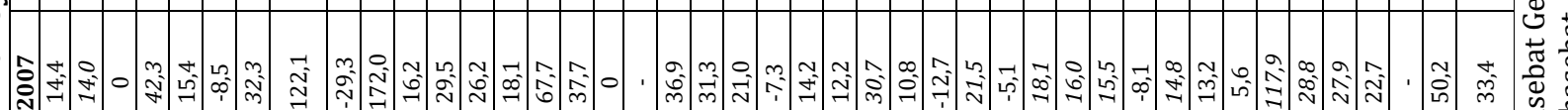
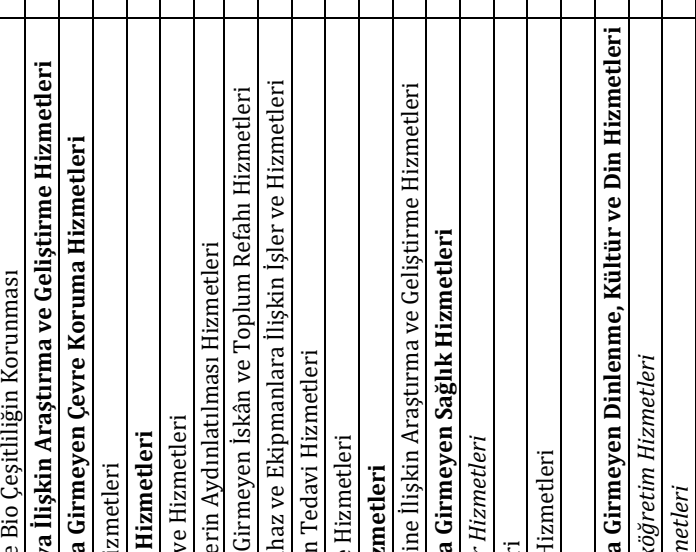
ulaşmak ve enflasyonun görünüşte artış etkisinden verilerin arındırılmak istenmesidir. Veriler 2006 yılından başladığı için 2007 yılından itibaren artış oranlarını izlemek mümkündür. Tabloya olumlu perspektiften bakıldığında, ilk dikkat çeken nokta 2011 yılından 2012 yılına geçişte Sosyal Güvenliği Bulunmayanlara Sağlanan Hizmetlere ${ }^{13}$ yönelik yapılan kamu harcamaları çarpıcı bir şekilde \%1385,5 artmasıdır ${ }^{14}$. Hatta aynı hizmet türünde 2010 yllından 2011 yllına gelindiğinde $-\% 26^{\prime} l \mathrm{k}$ bir azalış söz konusuyken, 2012 yılından itibaren bu kalemde artış eğilimi yaşanmıştır. Bu sonuç ise 2012 yılından itibaren durum iyileştirilmesi yükümlülüğüne uyulduğuna işaret etmektedir. Sosyal güvenliği bulunmayanlara sağlanan hizmetlere yönelik yapılan kamu harcamalarının artış ortalaması ise \%133,8 olup, bu sonuç dezavantajlı grupların durumlarının iyileștirilmesi açısından önemli bir sonuçtur.

Tablo 4 genel olarak değerlendirildiğinde, harcamaların artışında dalgalı bir seyir izlemektedir. Örneğin; sivil savunma, atık su yönetimi hizmetleri, çevre korumaya ilişkin araștırma ve geliştirme hizmetleri, sınıflandırmaya girmeyen sağlık hizmetleri, sınıflandırmaya girmeyen dinlenme, kültür ve din hizmetleri kapsamında gerçekleşen harcamaların artış oranı bazı yıllarda oldukça yüksek iken, bazı yıllarda ise bu oran eksilere kadar düşmektedir. Başka bir ifadeyle; gerçekleşen harcamaların artış oranlarının eksi

\footnotetext{
${ }^{13}$ Bu kapsamda yer alan hizmetler: "1. Toplum dıșı birakılan ya da toplum dışs bırakılma riskini taşıyan kişilere yapılan ayni ve nakdi yardım şeklindeki sosyal yardımlar (ör. Yoksullar, düşük gelir seviyesine sahip kişiler, göçmenler, mülteciler, alkol ve uyuşturucu madde bağımlısı kişiler, suç ve şiddet kurbanları, vb.),

2.Bu tür sosyal koruma planlarının yönetimi, isletimi ya da desteklenmesi, 3.Yoksulluğu azaltmak ve zor durumlarda destek olmak için yoksullara ve korumasız kimselere yapılan gelir yardımları ve diğer nakit ödemeler gibi nakdi yardımlar

4.Yoksul ve korumasiz kimselere yapılan kısa vadeli ve uzun vadeli barınma ve yiyecek içecek yardımları, alkol ve uyușturucu madde bağımlılarının rehabilitasyonu, korumasız kimselere yardım için verilen mal ve hizmetler, rehberlik, gündüz barınma, günlük islerin yürütülmesinde yardım, yiyecek, giysi, yakıt, vb. gibi ayni yardımlar" (ABS İliskin Rehber, ss.131-132).

${ }^{14}$ Sağlık yardımı dâhilinde yeşil kart ile karşılanmayan veya yeșil karta sahip olmayanların ödeme gücü üzerindeki sağlık harcamaları ile sosyal güvencesi bulunmayanların tedavi ve ilaç giderleri
}

olduğu yıllarda durum iyileștirilmesi yükümlülügü ihlal edilmiştir.

Ele alınan oranların dalgalı bir seyir izlemesi nedeniyle ilgili yıllarda durum iyileştirilmesi yükümlülüğüne kesinlikle uyulmuştur gibi bir sonuca varmak doğru değildir. Çünkü durum iyileştirilmesi yükümlülügüne göre devletlerin ekonomik, sosyal ve kültürel hakların desteklenmesi konusunda belirli ve sürekli bir yükümlülügü bulunmaktadır. Devletler, güçlü gerekçeleri olmadıkça mevcut hakların kötüleşmesine izin veremezler. Tabloyu daha basitleștirmek ve resmi bütün görmek amacıyla Tablo 4'ün en sol sütununda 2007-2018 yıllarının ortalaması hesaplanmıştır. İlgili yılların ortalamalarına göre; incelenen sivil savunma hariç her bir bütçe kaleminde gerçekleșen harcamalarda artış yaşanmıștır. Sadece sivil savunma harcamalarında meydana gelen artış oranının ortalaması \%-2,5'tir. Sivil savunma hizmetine yönelik 2007-2018 arası ortalama artış oranının eksi çıkmasının en önemli sebebi 2018 yılında sivil savunma hizmetlerine yönelik gerçekleșen harcamalarda 2017 yılına nazaran \%61,1'lik azalışın yaşanmasıdır. Ek 2 kısmından da takip edileceği üzere, 2017 yılında bu hizmet kalemi için 66962 bin TL harcanmış iken, 2018 yılında sadece 25.991 bin TL harcanmıştır.

İlave olarak, (i) Atık su yönetimi hizmetleri, (ii) Kirliliğin azaltılması hizmetleri, (iii) Çevre korumaya ilişkin araştırma ve geliştirme hizmetleri, (iv) Sınıflandırmaya girmeyen çevre koruma hizmetleri, (v) Toplum refahı

karssılanmaktayken, 01.01.2012 tarihi itibarıyla 5510 sayılı Sosyal Sigortalar ve Genel Sağlık Sigortası Kanunu kapsamında Genel Sağlık Sigortası (GSS) hükümlerinin yürürlüğe girmesiyle bütün vatandaşların sağlık ve tedavi hizmeti tutarları Genel Sağlı Sigortası kapsamına alınmıştır (Tunç, 2015:195). Böylece “Dokuzuncu Kalkınma Planı (2007-2012) kapsaminda ekonomik gelișmelerin yanında sosyal kalkınma yönünde önemli ilerlemeler sağlanmış ve sosyal içerme ile yoksullukla mücadele amaciyla daha kapsayıcl bir sosyal güvenlik sistemi, daha etkin ve yaygın bir sosyal destek sistemi oluşturulmuştur" (Kalkınma Bakanlığı, 2013:23-43). "2012 Orta Vadeli Program kapsamında ise Gelir dağılımının iyileștirilmesi ile yoksulluk ve sosyal dışlanma riski altında bulunan birey ve grupların; ekonomik ve sosyal hayata katılımlarının artırılması, yașam kalitelerinin yükseltilmesi ve toplumla bütünleşmelerinin sağlanması temel amaçlardır" (Kalkınma Bakanlığı, 2011:53). Ayrıca 2012 yılında sosyal koruma harcamalarının artmasında Suriyeli mültecilere yönelik yapılan insanı yardım harcamaların da etkisi vardır (Yentürk, 2012:5). 
hizmetleri, (vi) Halk sağlığı hizmetleri, sinıflandırmaya girmeyen sağlık hizmetleri, (vii) Sinıflandırmaya girmeyen dinlenme, kültür ve din hizmetleri, (viii) Hastalık ve malullük yardım hizmetleri, (ix) Sınıflandırmaya girmeyen eğitim hizmetler ve (x) Sosyal güvenliği bulunmayanlara sağlanan hizmetlere yönelik gerçekleşen kamu harcamalarının artış ortalaması \%30'dan daha fazladır. Sonuç olarak denilebilir ki; incelenen 12 yıllık süreçte zaman zaman durum iyileștirilmesi yükümlülügüne uyulmasa bile, son sol sütunda yer alan ortalama artış rakamlarının hemen hemen hepsinin pozitif olması arzu edilen bir neticedir.

Aşamalı gerçekleştirme yükümlülüğü, durum iyileștirmesi yükümlülüğü ile yakından ilişkilidir. Çünkü aşamalı gerçekleştirme yükümlülüğü kapsamında devletler insan haklarının sağlanması noktasında sürekli bir gelișim göstermek zorundadır. Öyleyse "Tablo 4'e ait veriler değerlendirildiğinde, güvenlik hizmetleri, mahkeme hizmetleri, cezaevi idaresi hizmetleri, sınıflandırmaya girmeyen kamu düzeni ve güvenlik hizmetleri, dinlenme ve spor hizmetleri, din hizmetleri, okul öncesi ve ilköğretim hizmetleri, ortaöğretim hizmetleri, yükseköğretim hizmetleri, eğitime yardımcı hizmetleri, hastalık ve malullük yardım hizmetleri, aile ve çocuk yardımı hizmetleri ve yaşlılık yardımı hizmetlerinde sürdürülebilir bir iyileşme yaşanmıștır" yorumunu yapmak yanlış olmayacaktır. Çünkü bu alt hizmet türlerine yönelik yapılan kamu harcamalarında sürekli bir artıș söz konusudur. Geri kalan hizmet türlerine yaplan harcamalarda ise bazı yıllarda azalış yaşanmıştır. ${ }^{15}$

\section{SONUÇ VE DEĞERLENDİRME}

Son yıllarda ekonomik, sosyal ve kültürel haklar diğer bir ifadeyle; insan hakları konusu oldukça önem kazanmıştır. Özellikle makroekonomik alanda insan haklarının korunması ve sürekliliğinin sağlanması amacıyla dikkate değer adımlar atılmıştır. Çalışmada 2006-2018 yılları arasında merkezi yönetim bütçesi verileri, insan haklarına duyarlı bütçeleme kapsamında analiz edilmiştir. İncelenen veriler önce maksimum mevcut kaynaklar yükümlülügü açısından incelenmiştir. $\mathrm{Bu}$ sebeple Tablo 3'te gerçekleşen kamu harcamalarının başlangıç ödeneklerine oranlarına yer verilmiştir. Tablo 3'ün son sütununda yer alan ortalamalar incelendiğinde, italik gösterilen toplam 15 hizmet türünde maksimum mevcut kaynaklar yükümlülügünün ihlal edildiği anlaşılmaktadır. Çünkü bu hizmet türlerinde kamu harcamalarının başlangıç ödeneklerine oranı $\% 100$ 'den daha az gerçekleşmiştir. Diğer bir ifadeyle; bu hizmet türlerinde başlangıçta taahhüt edilen bütçe ödeneklerinin tamamı harcanmamıştır. Ortalamalar sütununda koyu punto ile gösterilen toplam 27 hizmet türünde bu oran \%100'den ve özellikle 11'inde ise $\% 120$ 'den fazladır. $\mathrm{Bu}$ netice maksimum mevcut kaynaklar yükümlülüğünün yerine getirilmesi açısından olumludur.

Tablo 4, hem durum iyileştirilmesi hem de aşamalı gerçekleştirme yükümlülükleri açısından değerlendirilmiştir. Ekonomik, sosyal ve kültürel haklara ilişkin kamu harcamaları yapılırken bu iki yükümlülüğe uyulup uyulmadığını belirlemek amacıyla kamu harcamalarının bir önceki yıla göre artış oranları üzerinden analizler gerçekleşmiştir. Durum iyileştirilmesi yükümlülüğü açısından Tablo 4 değerlendirildiğinde, eksi rakamlar ilgili yıllarda gerçekleşen kamu harcamalarının bir önceki yıla göre azaldığı anlamına gelmektedir. Bu netice ise durum iyileștirilmesi yükümlülügünün göz ardı edildiği sonucuna götürmektedir. En sağda yer alan ortalamalar sütunu değerlendirildiğinde, Tablo 4'te koyu punto ile gösterilen 11 hizmet türünde ilgili oran \%30'dan daha fazladır. Özellikle sosyal güvenliği bulunmayanlara sağlanan hizmetlerde 2007-2018 arası harcamaların ortalama artış oranı \%133 olarak 
gerçekleşmiştir. İlgili artışın ardında yatan en önemli neden ise 2012 yllında bu hizmetin gerçekleşmesinde bir önceki yıla nazaran \%1385,6'lık bir artışın meydana gelmesidir. Bu artışın ardında ise (i) 2012 yllında GSS hükümlerinin yürürlüğe girmesi ve tüm vatandaşların tedavi ve sağlık bedellerinin GSS kapsamına alınması, (ii) 10. Kalkınma Planı ve 2012 Yll Orta Vadeli Program'da da vurgulandığı üzere yoksullukla mücadele amacıyla daha kapsayıcı bir sosyal güvenlik sistemi, daha etkin ve yaygın bir sosyal destek sistemi olușturulma hedefi ve (iii) Suriye'den göç eden mültecilere yapılan yardımlardaki artışlar gösterilebilir.

Așamalı gerçekleștirme yükümlülüğü açısından Tablo 4 incelendiğinde, italik gösterilen 12 alt hizmet türünde 2007-2018 yılları arasında kamu harcamalarında sürekli bir artış yaşanmıștır. Toplam 12 alt hizmet türünde aşamalı gerçekleștirme yükümlülügüne tamamen uyulmuştur demek yanlış olmayacaktır. Özellikle eğitim hizmetleri ikinci düzeyini oluşturan hizmet türlerinin çoğunda sürdürülebilir bir iyileşme yaşanmıştır. Ancak diğer hizmet türleri açısından durum değerlendirilmesi yapıldığında, bazı yıllarda gerçekleşen kamu harcamalarında azalışlar söz konusudur. Azalışların olduğu hizmet türlerinde ise aşamalı gerçekleștirme yükümlülüğünün ihlali söz konusudur.

Sonuç olarak, 1945 yılından itibaren Birleşmiş Milletler' in bir üyesi olan Türkiye'de ekonomik, sosyal ve kültürel hakların sağlanması konusunda önemli adımlar atılmaktadır. Merkezi yönetim bütçesinin 2006 yılı ve sonrası verileri analiz edildiğinde, özellikle dezavantajlı durumda olan bireylerin temel eğitim, acil sağllk, barınma, gıda vb. açıdan desteklenmesi noktasında sürdürülebilir bir gelişmeden söz edilebilir. Ancak bazı yıllarda Birleșmiş Milletler tarafindan belirlenen yükümlülüklere uyulmamasına istinaden, daha kat edilmesi gereken mesafenin olduğu düşünülmektedir. Bu sebeple ilerleyen dönemlerde daha etkin bir şekilde uygulanacak sosyo-ekonomik ve sosyokültürel temelli reform önerilerinin ve kararların hayata geçirilmesi ile mevcut sorunların minimize edileceği arzu edilmektedir.

\section{REFERANSLAR}

AĞIR, H. ve TIRAŞ, H. H. (2018). Türkiye'de Sağlık Harcama Türlerinin Değerlendirilmesi. Kahramanmaraş Sütçü İmam Üniversitesi Sosyal Bilimler Dergisi. 15(2), 643-670.

ALLEN, I., M. MANION, T. MATTHEWS, and R. RALSTON (2016). Human Rights Watch Advisory Project Report, Humphrey School of Public Affairs. University of Minnesota, USA.

ALSTON, P. (2004). A Human Rights Perspective on the Millennium Development Goals. Background Paper For The UN Millennium Project Task Force on Poverty and Economic Development. UN Millennium Project, New York.

ATAER, M. Y. ve EFE, G. N. (2016). Türkiyede Sosyal Harcamaların Gelişimi ve Seçilmiş Ülkelerle Karşılaştırmalı Analizi. Instutions Society \& Economic Development. M. M.
ERDOĞDU, M., A. Sofranijevic and S. Akar (eds.). 89-100. ICOPEC Publications: No. 21. Londan, the UK.

BAYRAMOĞLU, A. (2004). Uluslararası Sistem ve İnsan Hakları Oturumu Açılıș Konuşması. Uluslararası İnsan Hakları Sempozyumu Bildiri Kitabı. Motif Matbaacılık. 11-12 Aralık. Bursa.

BİLGEN, A. (2004). Öncelikli İnsan Hakları Konuları. Uluslararası İnsan Hakları Sempozyumu Bildiri Kitabı. Motif Matbaacılık. 11-12 Aralık. Bursa.

BLYBERG, A. (2015). Human Rights Budgeting and Budget Analysis. The Scottish Human Rights Commission (SHRC). www.scottishhumanrights.com (30.01.2018).

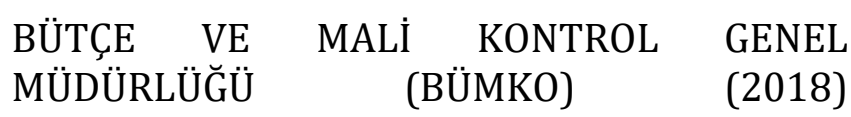


http://www.bumko.gov.tr/Eklenti/612,abstan itim2007pdf.pdf?0, 31.05.2018.

\section{BÜTÇE VE MALİ KONTROL GENEL MÜDÜRLÜĞÜU (BÜMKO) (2018). http://www.bumko.gov.tr/TR,165/merkezi- yonetim-butce-giderleri-2006-2017.html, 31.05.2018.}

CHARMAN, A. R. and S. RUSSELL (2002). Core Obligations: Building a Framework for Economic Social and Cultural Rights. Antwerp: Intersentia, New York, USA.

ÇELIKK, Y. (2011). Türkiye Sağlık Harcamalarının Analizi ve Sağlık Harcama Düzeyinin Uygunluğunun Değerlendirilmesi. Sosyal Güvenlik Dergisi. 1, 62-81.

ÇİÇEK, Ş. E. ve DİKMEN, S. (2016). Sosyal Bütçeleme Örneği Olarak Çocuk Dostu Bütçe. Ekonomik ve Sosyal Araștırmalar Dergisi. 12(2), 131- 147.

ÇOŞKUN, V. (2004). İnsan Haklarının Korunması ve Yargı. Uluslararası İnsan Hakları Sempozyumu Bildiri Kitabı. Motif Matbaacılık. 11-12 Aralık. Bursa.

EGELI, H. ve ATILGAN YASA, A. (2017). Devlet Bütçesi Açısından Adalet Hizmetleri ve Harcamaları: Türkiye Üzerine Bir Değerlendirme. Eskişehir Osmangazi Üniversitesi İIBF Dergisi. 2(2), 83-94.

ELSON, D., B. RADHIKA, and J. HEINTZ (2011). Public Finance, Maximum Available Resources and Human Rights. Human Rights and Public Finance Budgets and the Promotion of Economic and Social Rights, Aoife Nolan, Rory O'Connell and Colin Harvey (Eds.) Oxford and Portland, Oregon, USA.

ELSON, D. (2006). Budgeting for Women's Rights: Monitoring Government Budgets for Compliance with CEDAW. United Nations Development Fund for Women (UNIFEM), New York, USA.

ESCR-Net (2019). Progressive Realisation and Non-Regression, https://www.escrnet.org/resources/progressive-realisationand-non-regression, 16.12.2019.
FLAC (The Free Legal Advice Centres) (2014), A Human Rights Approach to Budgeting. https://www.flac.ie/publications/briefinghuman-rights-approach-to-budgeting/, 20.12.2019.

FUNDAR (2004). Dignity Counts: A Guide to Using Budget Analysis to Advance Human Rights. International Human Rights Internship Program, International Budget Project, ISBN 09707700-4-9, Fundar - Centro de Análisis e Investigación, Mexican.

GERMAN INSTITUE OF HUMAN RIGHTS (2010). Human Rights Budgeting. http://www.institut-

fuermenschenrechte.de/uploads/tx_commerc e/e-info-tool_hr_budgeting.pdf, 22.01.2018.

GÖZLER, K. (2017). İnsan Hakları Hukukuna Giriş. (1. Baskı). Ekin Basım Yayın Dağıtım, Bursa.

GÖZLER, K. (2000). Türk Anayasa Hukuku. (1. Baskı). Ekin Basım Yayın Dağıtım, Bursa.

GTZ (Deutsche Gesellschaft für Technische Zusammenarbeit) (2010). Human Rights Budgeting, http://www.institut-fuermenschenrechte.de/uploads/tx_commerce/einfo-tool_hr_budgeting.pdf (30.01.2018).

GÜNLÜK ŞENESEN, G., YÜCEL, Y. YAKAR ÖNAL, A., ERGÜNEŞ, N. ve YAKUT ÇAKAR, B. (2017). Kadınsız Kentler Toplumsal Cinsiyet Açısından Belediyelerin Politika ve Bütçeleri. İstanbul Bilgi Üniversitesi Yayınları, İstanbul.

GÜNGÖR GÖKSU, G. (2018). Çocuk Dostu Şehirlerin Kurulmasında Çocuklara Duyarlı Bütçelemenin Önemi ve Rolü. Sayıştay Dergisi. 110, 157-169.

GÜNGÖR, G. ve GÖKSU, A. (2013). Türkiye'de Eğitimin Finansmanı ve Ülkelerarası Bir Karşılaştırma. Yönetim ve Ekonomi Dergisi. 20(1), 59-72.

HENSTSCHEL A. K. and REBHAN C. (2008). Social and Human Rights Budgeting-Budget Monitoring, Participatory Budgeting and Human Rights. Conference Report, Berlin, https://gsdrc.org/document-library/social- 
İzmir İktisat Dergisi (İzmir Journal of Economics) , Yıl: 2019, Cilt:34, Sayı:4, ss. 599-621

and-human-rights-budgeting-budgetmonitoring-participatory-monitoring-andhuman-rights/, 30.06.2018.

KAYALIDERE, G. ve ŞAHIN (2014). Sosyal Devlet Anlayışı Çerçevesinde Türkiye'de Sosyal Koruma Harcamalarının Gelişimi ve Yoksulluk. Siyaset, Ekonomi ve Yönetim Araştırmaları Dergisi. 2(2), 57-75.

KUÇURADI, I. (1996). Felsefe ve İnsan Hakları. İnsan Haklarının Felsefi Temelleri. Kuçuradi, I. (ed.), (s.49-54) Türkiye Felsefe Kurumu, Ankara.

LEVIN, L. (1987). Human Rights: Questions and Answers, United Nations (UN). Educational, Scientific and Cultural Organization (UNESCO), 7 Place de Fontenoy, Paris.

MANION, M., R. RALSTON, T. MATTHEWS, and I. ALLEN (2017). Budget Analysis as a Tool to Monitor Economic and Social Rights: Where the Rubber of International Commitment Meets the Road of Government Policy. Journal of Human Rights Practice. 9(1), 146-158.

MERIÇ, M. (2013). "Bütçe Sistemlerinde Dönüşüm ve Değişim”, Kamu Bütçesinde Yeni Yaklaşımlar, Figen Altuğ, Ahmet Kesik, Murat Şeker (Ed.), ISBN:978-975-02-2372-3, Seçkin Yayınları, Ankara.

MUHASEBAT GENEL MÜDÜRLÜĞÜ (2019). https://muhasebat.hmb.gov.tr/merkeziyonetim-butce-istatistikleri, 17.12.2019.

MUTUA, M. (1996). The Ideology of Human Rights. Virginia Journal of International Law. 36, 589-657.

O'CONNEL, R. (2017). Human Rights and Fiscal Oversight: A Case Study of the Northern Ireland, 2011-15 Budget. Journal of the Institute of Public Administration. 65(3), 8399.

O'CONNEL, R. (2013). Recovering the History of Human Rights: Public Finances and Human Rights. Human Rights and Public Finance Budgets and the Promotion of Economic and Social Rights, Aoife Nolan, Rory O'Connell ve
Colin Harvey (Eds.), Oxford and Portland, Oregon.

OHCHR (Office of the United Nations High Commissioner for Human Rights) (2009). Report of the High Commissioner for Human Rights on Implementation of Economic, Social and Cultural Rights. E/2009/90, United Nations Office at Geneva, Switzerland.

OHCHR (The Office of the United Nations High Commissioner for Human Rights) (2008). Frequently Asked Questions on Economic, Social and Cultural Rights. Fact Sheet No. 33, United Nations Office at Geneva, Switzerland.

PWESCR (Programme on Women's Economic, Social and Cultural Rights) (2015). Human Rights for All International Covenant on Economic, Social and Cultural Rights A Handbook. Programme on Women's Economic, Social and Cultural Rights, The Netherlands.

SHUE, H. (1996), Basic Rights: Subsistence, Affluence and U.S. Foreign Policy, Princeton University Press, USA.

ŞAHIN TAŞĞIN, N. (2017). Yoksulluk İnsan Hakları ve Sosyal Hizmetler, Değișen Anlayıșlar: Refah Devletinden Hayırseverliğe Yoksulluktan Sosyal Dışlanmaya. (1.Baskı) Nika Yayınları, Ankara.

T.C. HAZINE ve MALIYYE BAKANLIĞI (2019). Analitik Bütçe Sınıflandırılmasına İlişkin Rehber, www.hmb.gov.tr, 20.12.2019.

T.C. KALKINMA BAKANLIĞI (2013). Onuncu Kalkınma Planı (2014-2018). Ankara.

T.C. KALKINMA BAKANLIĞI (2011). Orta Vadeli Program (2012-2014), Ankara.

T.C. STRATEJI VE BÜTÇE BAȘKANLIĞI (2018). On Birinci Kalkınma Planı (2019-2023). Ankara.

T.C. TÜRKIYE BÜYÜK MILLET MECLİII (TBMM) (2006). 2007 Malî Yılı Merkezî Yönetim Bütçe Kanunu Tasarısı İle 2005 Malî Yılı Genel ve Katma Bütçe Kesin Hesap Kanunu Tasarılarının Plan ve Bütçe Komisyonu Görüșme Tutanakları, https://www.tbmm.gov.tr/butce/2007/pbk29 112006.htm,16.12.2019 
T.C. 1982 ANAYASASI (1982). Resmi Gazete. 9/11/1982 tarih ve Sayl:1786.

THE UNITED NATIONS (2007). An Evaluation of the Obligation to Take Steps to the 'Maximum of Available Resources' under an Optional Protocol to the Covenant. E/C.12/2007/1 Committee on Economic, Social and Cultural Rights, Switzerland.

TOPRAK, D., AĞCAKAYA, S. ve GÜL, H. (2016). Sosyal Devlet Yaklaşımı Açısından Türkiye'de 1980 Sonrası Eğitim Harcamalarının Analizi. Dokuz Eylül Üniversitesi, İktisadi ve İdari Bilimler Fakültesi Dergisi. 31(1), 123-165.

TUNÇ, A. (2015). Yeni Kamu Yönetimi Anlayışı Açısından "Sosyal Yardım Yönetimine Yönelik Bir Değerlendirme. Akademik Araștırmalar ve Çalışmalar Dergisi. 7(13), 190-206.

THE UNITED NATIONS DEVELOPMENT PROGRAMME (2015). Human Rights and the Millennium Development Goals: Making the Link. Oslo Governance Centre. Oslo, Norway.

VIYANA BEYANNAMESI VE EYLEM PROGRAMI, 25 Temmuz 1993, https://www.ohchr.org/EN/ProfessionalInter est/Pages/Vienna.aspx, 29.12.2019.

WRIGHT, S. (2001). International Human Rights, Decolonisation and Globalisation. Becoming Human. Routledge. London.

YENTÜRK, N. (2012). Türkiye'de Sosyal Koruma Harcamaları: 2006-2013 Harcama İzleme Güncelleme Notu. https://stk.bilgi.edu.tr/media/uploads/2015/ 02/01/bilginotusosyalkoruma.pdf, 20.12.2019.

YILDIZ, S. ve UĞUR, A. (2016). Cinsiyete Duyarlı Bütçeleme ve Ülke Deneyimleri. MANAS Sosyal Araştırmalar Dergisi. 5(3), 271-292. 


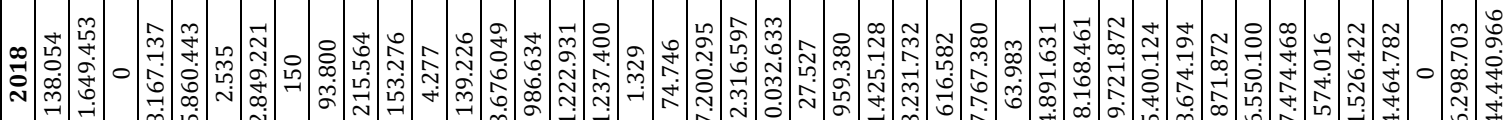

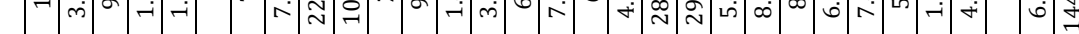

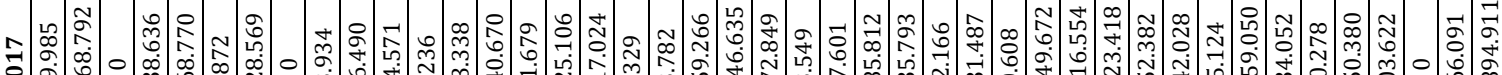

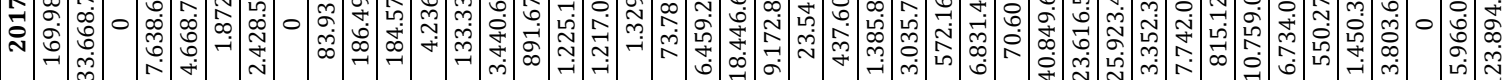

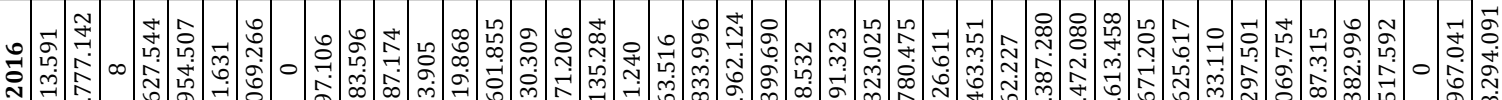

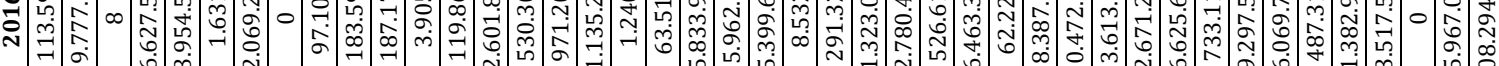

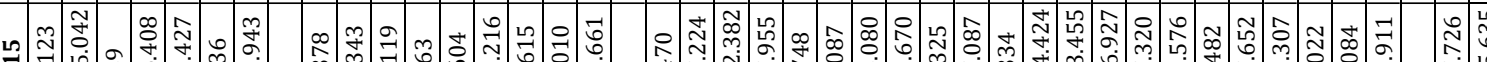

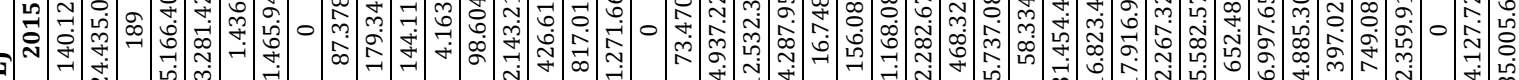

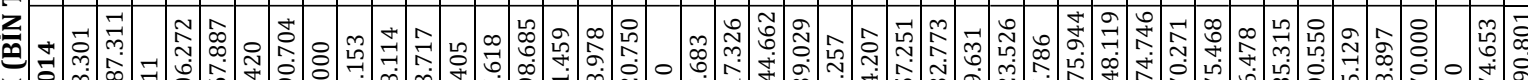

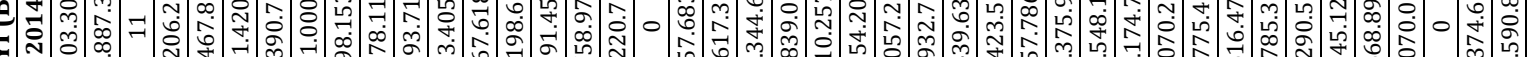

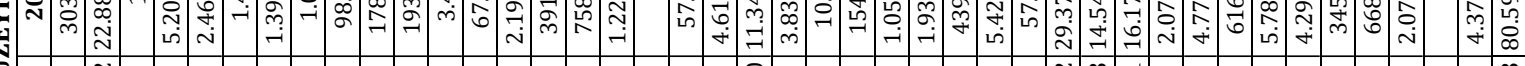

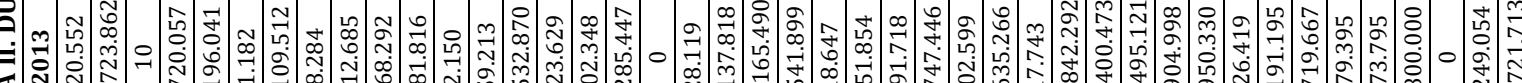

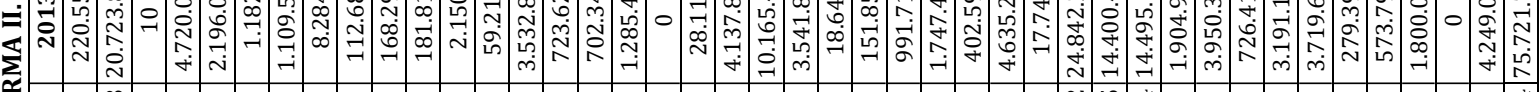

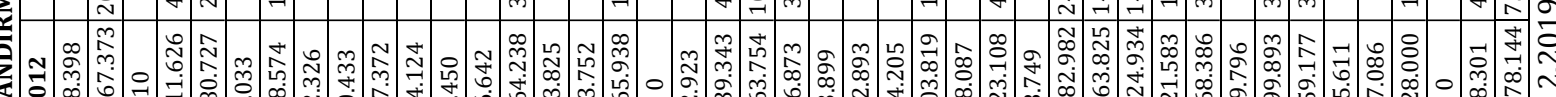

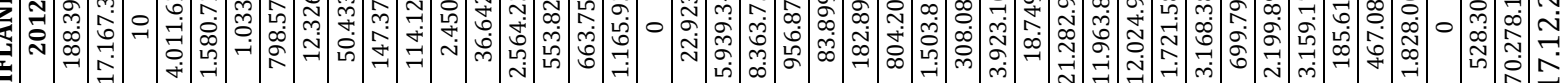

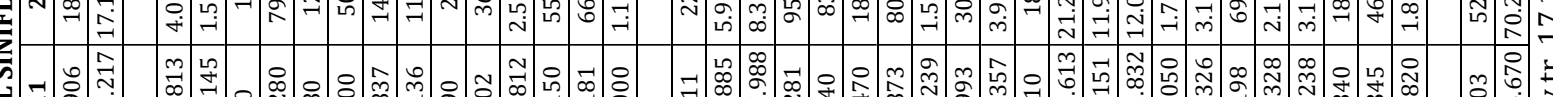

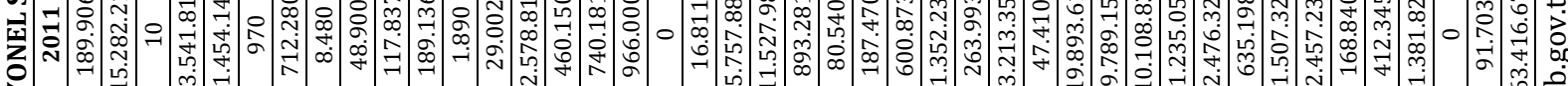

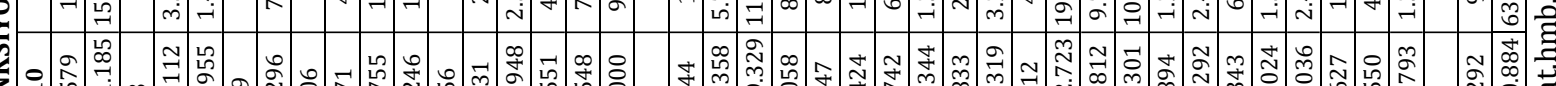

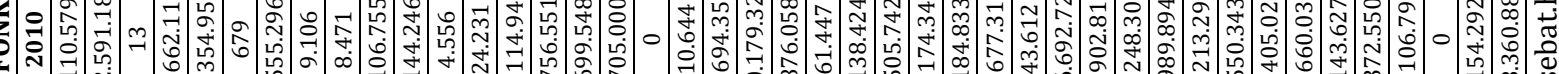

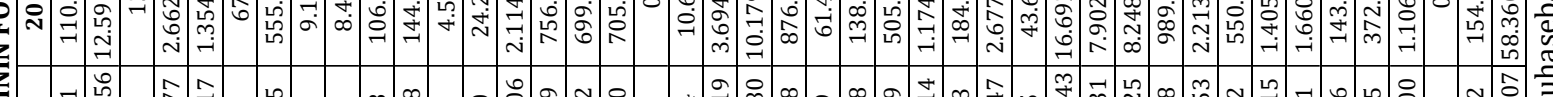

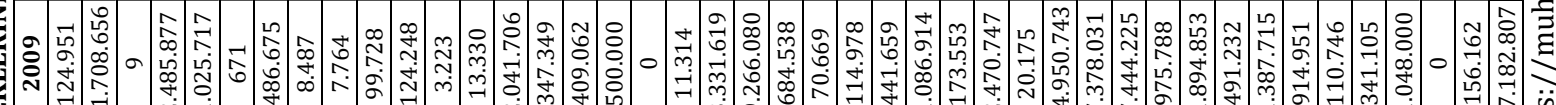

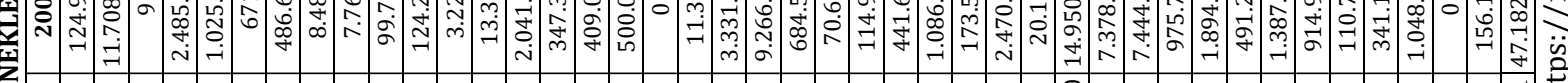

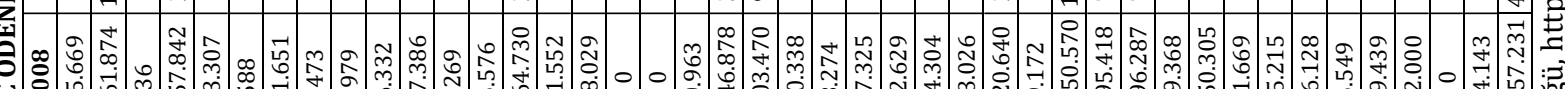

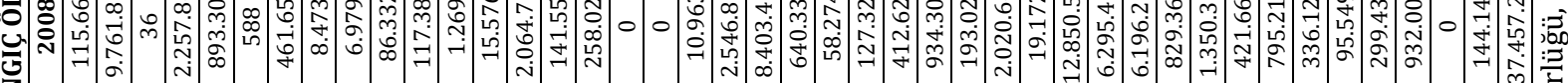

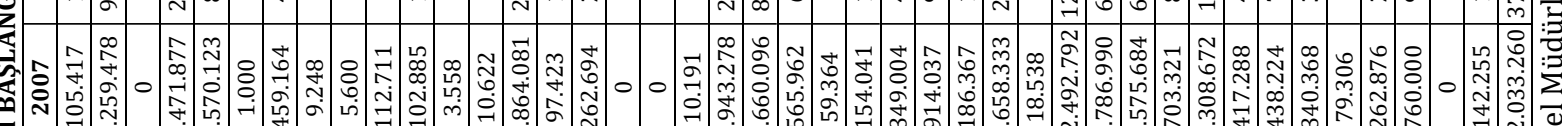

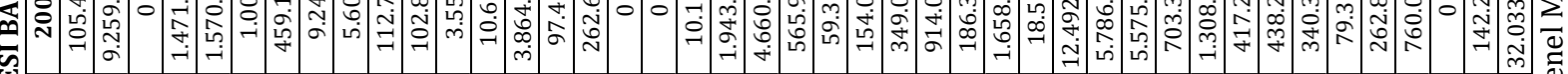

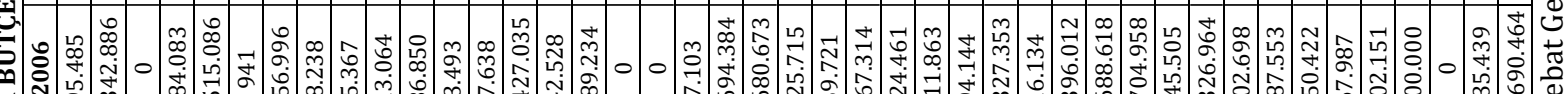

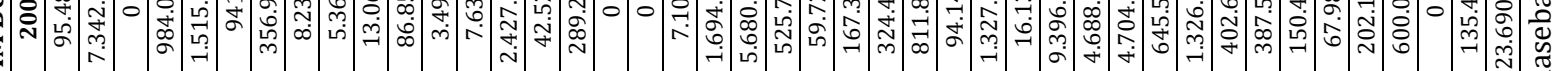

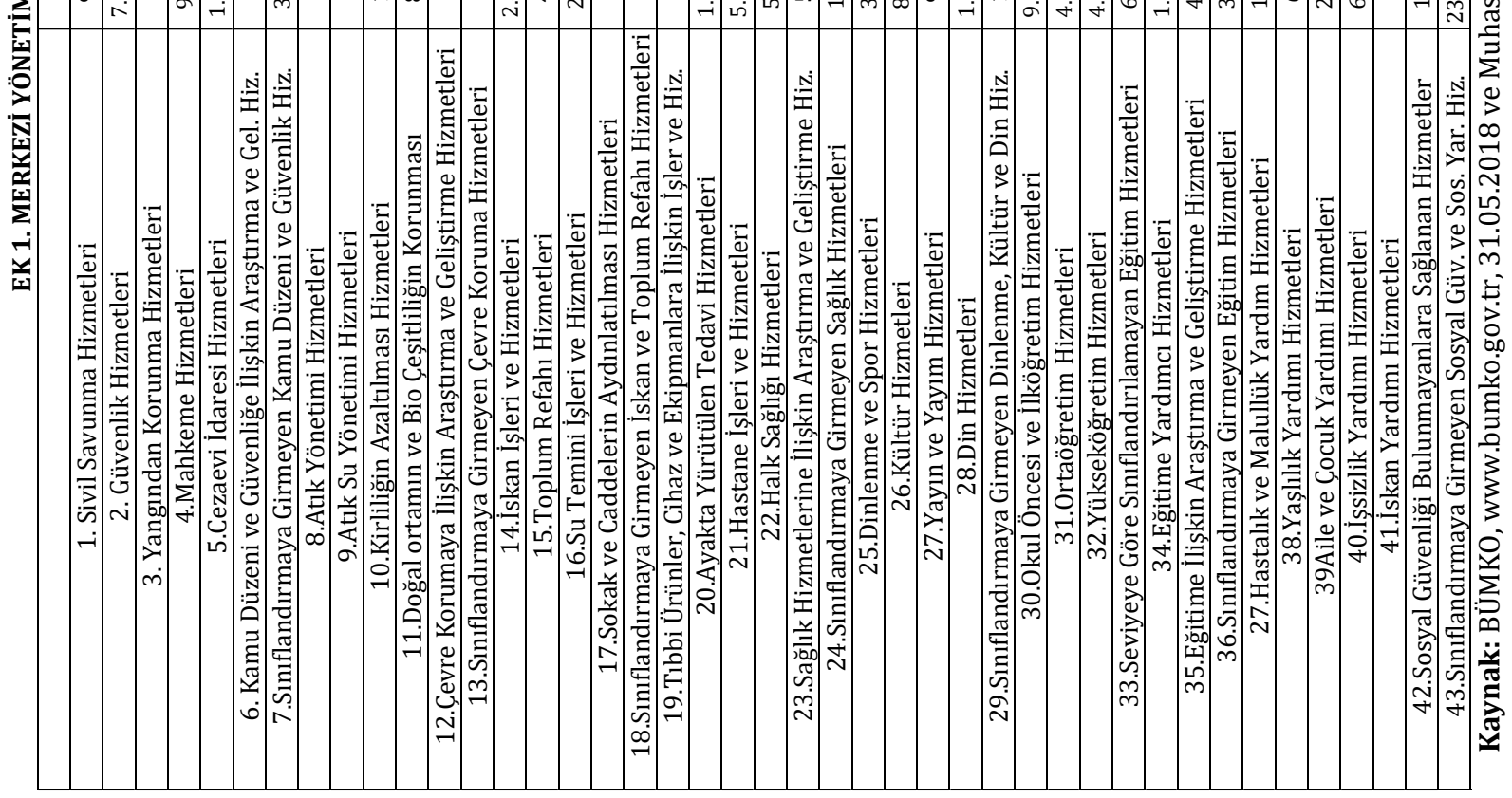




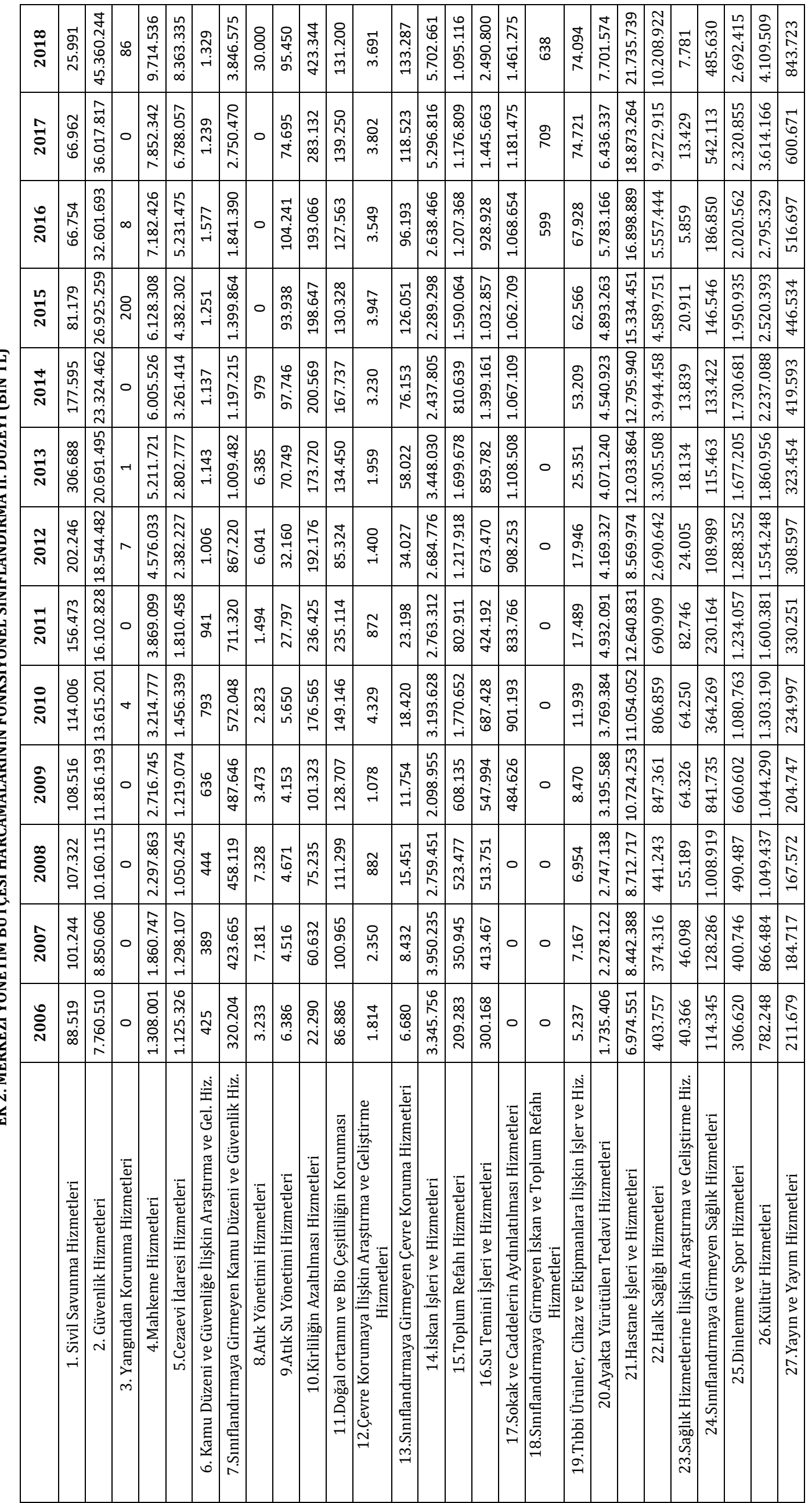




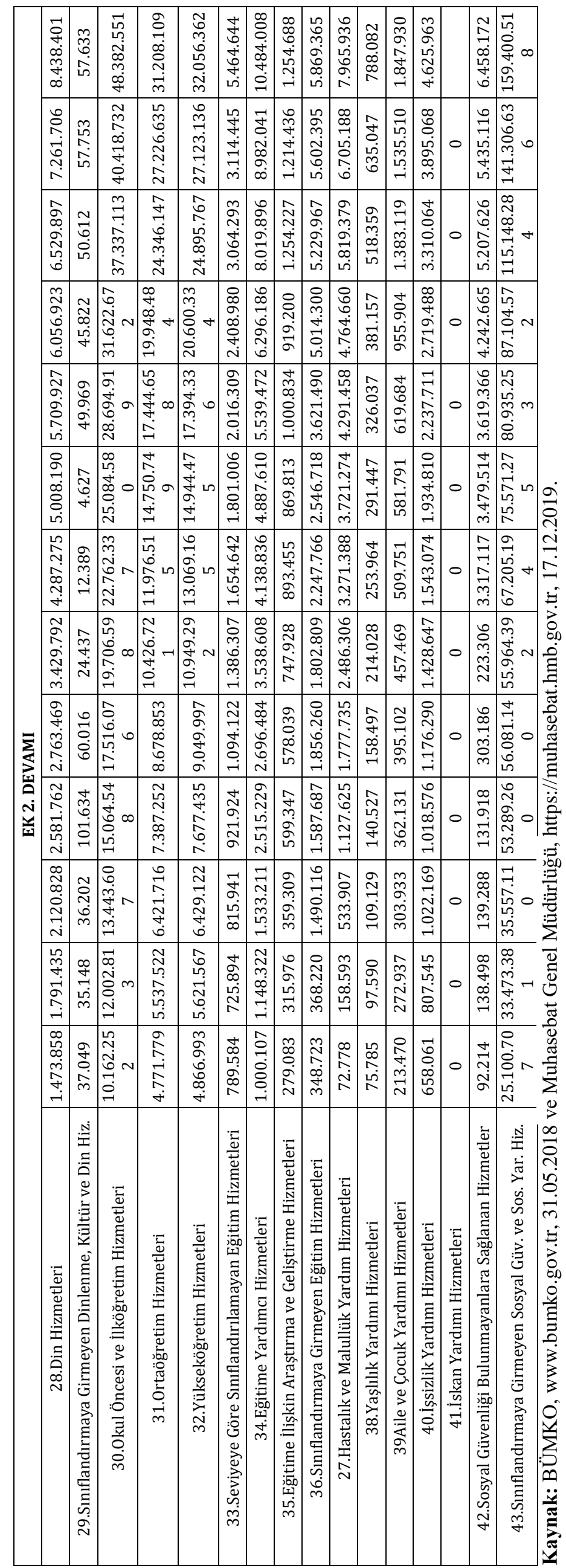

